\title{
Polymer Microstructure Control in Catalytic Polymerization Exclusively by Electronic Effects of Remote Substituents
}

\author{
Amaia Bastero, ${ }^{a}$ Inigo Göttker-Schnetmann, ${ }^{\text {a Caroline Röhr, }}{ }^{\mathrm{b}}$ \\ and Stefan Mecking ${ }^{\mathrm{a}, *}$ \\ a Lehrstuhl für Chemische Materialwissenschaft, Fachbereich Chemie, Universität Konstanz, Universitätsstrasse 10, \\ 78457 Konstanz, Germany \\ Fax: (+49)-7531-88-5152; e-mail: stefan.mecking@uni-konstanz.de \\ b Institut für Anorganische und Analytische Chemie, Universität Freiburg, Albertstr. 21, 79104 Freiburg i. Br., Germany
}

Received: December 12, 2006; Revised: June 6, 2007

Abstract: A series of $\left(\kappa^{2}-N, O\right)$ salicylaldiminato nickel methyl pyridine complexes 8a-h-pyr bearing 2,6-di-(4-R'-phenyl)phenyl groups on the imine nitrogen and varying in the remote substituents $\left[\mathbf{R}^{\prime}=\right.$ $\mathrm{C}_{8} \mathrm{~F}_{17}(\mathbf{a}), \mathrm{CF}_{3}$ (b), F (7c), $\mathrm{H}$ (d), Me (e), tert.-butyl (f), OMe (g), and $\left.\mathrm{NMe}_{2}(\mathbf{h})\right]$ were studied as precatalysts for ethylene polymerization. Complexes 8a-hpyr catalyze the polymerization of ethylene to low molecular weight polyethylene. Decreasing molecular weight and increasing degrees of branching are observed in the order $\mathrm{R}^{\prime}=\mathrm{C}_{8} \mathrm{~F}_{17} \approx \mathrm{CF}_{3}>\mathrm{F}>\mathrm{H}>$
$\mathrm{Me}>\mathrm{MeO}>$ tert-butyl $>\mathrm{NMe}_{2}$. X-Ray diffraction analysis of complex 8c-pyr and polymerization results obtained with complexes 8-pyr indicate that it is not the sterics but the electronics of the $\mathrm{R}^{\prime}$ group that control the polymer microstructure. This is a rare example of a polymerization catalyst in which substituents effects can clearly be traced to electronics exclusively.

Keywords: catalyst design; electronic structure; nickel; polymerization

\section{Introduction}

In the last decade families of highly active late transition metal catalysts for the polymerization of olefins have been developed, ${ }^{[1]}$ for example, cationic nickel and palladium diimines, ${ }^{[2]}$ iron and cobalt bis(imino)pyridine complexes, ${ }^{[3]}$ neutral salicylaldiminato nickel, ${ }^{[4]}$ anilinotropone nickel, ${ }^{[5]}$ and enolatoimine nickel complexes. ${ }^{[6,7]}$ Most commonly these catalysts bear a 2,6-diisopropylphenylimine moiety whose bulky isopropyl substituents effectively suppress chain transfer reactions by blocking axial positions at the metal center, and thus enable the generation of high molecular weight materials as opposed to olefin oligomerization products. ${ }^{[8]}$ With regard to ethylene homopolymers an impressive range of microstructures from strictly linear semicrystalline to highly branched amorphous polymers is accessible nowadays with these catalysts by adjusting polymerization parameters such as ethylene pressure and temperature or by switching to a different catalyst family. In contrast, only few examples are studied in detail where adjustable polymer microstructures result from modification of the substitution pattern of the bi- or tridentate $\widehat{\mathrm{NN}}$, $\overparen{\mathrm{NO}}$, or $\overparen{\mathrm{NNN}}$ ligands in a given catalyst family. ${ }^{[9,10 \mathrm{~b}]}$ Rieger et al. ${ }^{[10]}$ have studied cationic palladium- and nickel $\alpha$-diimine complexes $\mathbf{1 , 2 - X}$ bearing 2,6-[di-(4$\mathrm{X}$-phenyl)]phenyl- ( $\mathrm{X}=\mathrm{H}, \mathrm{OMe}, i$-Pr, $t$-Bu) instead of the 2,6-diisopropylphenyl-substituent on the imine nitrogens in the polymerization of ethylene (Figure 1). Particularly, the respective nickel precatalysts $\mathbf{2 - X}$, when activated with MAO, proved to be highly active polymerization catalysts. Noteworthy, however, the polymer microstructures were not significantly altered with variation of $\mathrm{X}$. Ultra high molecular weight materials with high melting point (i.e., low degree of branching) were obtained with all complexes 2-X. Closely related cyclophane-based palladium and nickel diimine complexes $\mathbf{3}$ and $\mathbf{4}$ with two terphenyl moieties double-linked by two $\mathrm{CH}_{2} \mathrm{CH}_{2}$ units exhibit a somewhat larger and more rigid pocket around the active site. Catalysts derived from the nickel analogue 4 (Figure 1) were found to be relatively stable also at high polymerization temperatures and even more active than $\mathbf{2 - X}$. The polyethylene generated by $\mathbf{4} /$ MAO under similar conditions studied for $\mathbf{2 - X}$ exhibits a narrow polydispersity $\left(\mathrm{M}_{\mathrm{w}} / \mathrm{M}_{\mathrm{n}}=c a\right.$. 1.3) (but lower molecular weight as compared to $\mathbf{2 - X}, \mathbf{M}_{\mathrm{w}} c a$. $390 \times 10^{3} \mathrm{~g} \mathrm{~mol}^{-1}$ ), and a high degree of branching ( $c a$. 65-70 branches per 1000 carbon atoms)..$^{[1,12]}$

Electronic modification of palladium precatalysts 5$\mathbf{Z}$ (Figure 1) originally employed by Brookhart et al. 


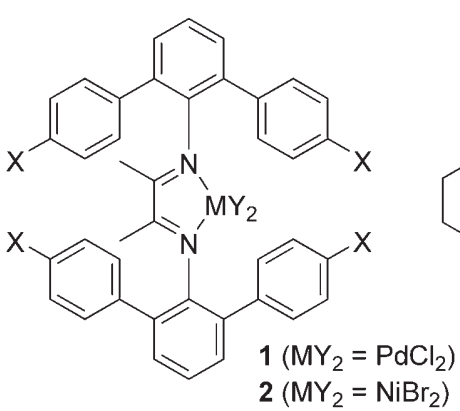

$\mathrm{X}=\mathrm{MeO}, \mathrm{H}, t-\mathrm{Bu}, \mathrm{SiMe}_{3}$

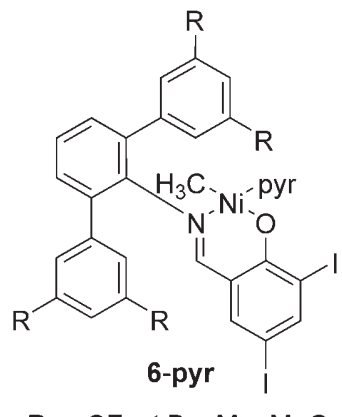

$\mathrm{R}=\mathrm{CF}_{3}, t-\mathrm{Bu}, \mathrm{Me}, \mathrm{MeO}$

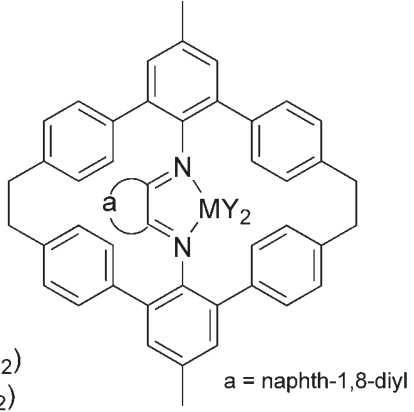

$3\left(\mathrm{MY}_{2}=\mathrm{PdCl}_{2}\right)$ $4\left(\mathrm{MY}_{2}=\mathrm{NiBr}_{2}\right)$

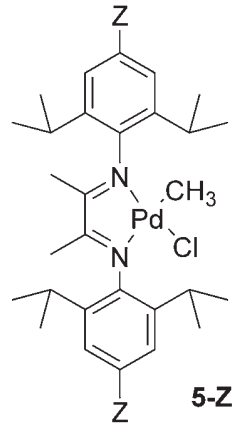

$\mathrm{Z}=\mathrm{NO}_{2}, \mathrm{CF}_{3}, \mathrm{Cl}, \mathrm{H}$

$\mathrm{Me}, \mathrm{MeO}, \mathrm{NMe}_{2}$

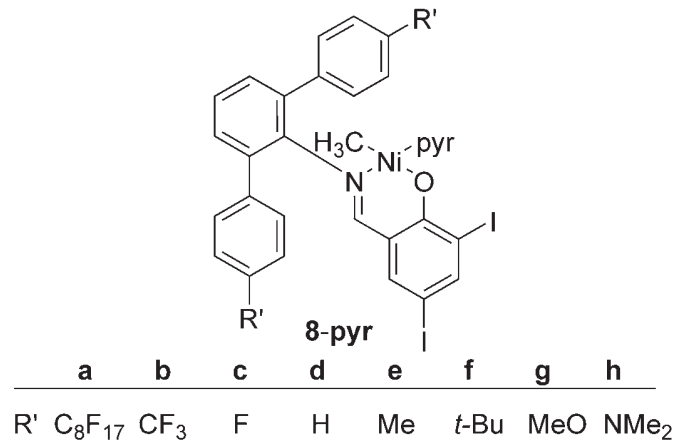

Figure 1. Complexes 1-5, 6-pyr and 8-pyr.

for olefin polymerization, when activated with $\mathrm{NaBAr}_{4}^{\mathrm{F}}$ in the presence of ethylene $\left(1 \mathrm{~atm}, 25^{\circ} \mathrm{C}\right)$ was reported by Guan et al. to result in formation of polyethylenes with a virtually identical degree of branching (94-100 branches per 1000 carbon atoms) while the molecular weight decreased with increasing electron deficiency of the $\mathrm{Z}$ substituents. Multi-angle light scattering experiments coupled to size exclusion chromatography revealed, however, that the branching topology given by the radius of gyration of the obtained polyethylenes is influenced by the electronics of the precatalyst, for example, more dendritic polyethylene (as concluded from smaller radii of gyration for a given $\mathrm{M}_{\mathrm{w}}$ ) was obtained with electron poor precatalyst 5- $\mathbf{N O}_{2}$ when compared to, for example, 5$\mathbf{N M e}_{2} \cdot{ }^{[13]}$ The apparently missing influence of the electronics of the $\mathrm{Z}$ substituent in catalysts $\mathbf{5 - Z}$ on the degree of branching in the obtained polyethylenes is likely linked to the tremendous differences in rates for chain walking and ethylene insertion as evidenced in the respective barriers. Detailed mechanistic studies conducted by Brookhart et al. for catalytically active species derived from $\mathbf{5}-\mathbf{H}$ reveal an upper limit for the barrier to chain walking of $\Delta G^{+}$chain walk $<$ $10.7 \mathrm{kcal} \mathrm{mol}^{-1}$, while the rate-limiting (averaged) barrier for chain growth from primary and secondary alkyl palladium olefin complexes (i.e., the barrier for ethylene insertion) is $\Delta G^{*}{ }_{\text {ins }}=c a .16 .9 \mathrm{kcalmol}^{-1} \cdot{ }^{[14]}$ If in a given catalyst $\Delta G^{\neq}$chain walk and $\Delta G^{\neq}{ }_{\text {ins }}$ were similar to one another, that is, rates for chain walking and insertion were similar (which is likely not the case in 5$\mathbf{Z}$ ), one should expect that small changes of these rates by steric or electronic fine-tuning of the metal center would significantly influence the ratio of chain walking to insertion and thus the degree of branching in the polymers obtained.

Due to their tolerance towards polar reaction media, neutral nickel(II) complexes are of interest for the synthesis of polyolefin nanoparticle dispersions by catalytic polymerization in aqueous systems. ${ }^{[15]}$ We have reported that $\left(\kappa^{2}-N, O\right)$ salicylaldiminato nickel methyl pyridine complexes 6-pyr bearing $m$-terphenyl groups depending on remote substituents placed in the $3^{\prime}, 5^{\prime}-$ positions of the distal phenyl rings (Figure 1) produce polyethylenes covering a wide range of microstructures and material properties under identical polymerization conditions. $^{[16]}$ For these complexes 6-pyr control of polyethylene microstructure was assumed to be related mainly to electronic rather then steric fine tuning of the nickel center. Recently, we have shown, that, though remote to the nickel center, in addition to electronic factors, steric modifications of these $3^{\prime}, 5^{\prime}$-substituents do still influence the molecular weight of the obtained polymers. ${ }^{[17]}$ In contrast to complexes $\mathbf{2 - X}, \mathbf{4}$, or $\mathbf{5 - Z}$, however, much less steric constraints are imposed on the terphenyl-groups in complexes 6-pyr. 
Here we report on a systematic study of a range of analogous complexes 8-pyr bearing electronically tuned 2,6-di-(4- $\mathrm{R}^{\prime}$-phenyl)phenyl groups $\left(\mathrm{R}^{\prime}=\mathrm{C}_{8} \mathrm{~F}_{17}\right.$, $\mathrm{CF}_{3}, \mathrm{~F}, \mathrm{H}, \mathrm{Me}$, tert-butyl, $\mathrm{MeO}, \mathrm{NMe}_{2}$ ), their catalytic activity in ethylene polymerization, and the microstructures of the polyethylenes obtained. By comparison to the $3^{\prime}, 5^{\prime}$-R-subtituents in complexes 6-pyr, substitution of the remote $4^{\prime}$-position in 8-pyr allows for a clear exclusion of steric effects on the catalytic behavior.

\section{Results and Discussion}

\section{Synthesis of $\left(\kappa^{2}-N, O\right)$-Salicylaldiminato Ni(II)- Methylpyridine Complexes 8-pyr}

Reaction of salicylaldimines 7a-h with [(tmeda)Ni$\left(\mathrm{CH}_{3}\right)_{2}$ ] in diethyl ether/pyridine, in analogy to procedures described earlier by us, yields pyridine complexes 8a-h-pyr in $77-87 \%$ isolated yield (Scheme 1, for details see Experimental Section). Complexes 8ah-pyr are stable for weeks at $25^{\circ} \mathrm{C}$ in benzene- $d_{6}$ solution without detectable decomposition. Characteristic features comprise observable ${ }^{4} J_{\mathrm{H}, \mathrm{H}}$ coupling constants (ca. 1.8-2.2 Hz) for the 4,6-protons of the 3,5-diiodosalicyl moeity, and high field resonances for the nickel bound methyl group in the ${ }^{1} \mathrm{H}$ NMR $(\delta=-0.42$ to $-1.06 \mathrm{ppm})$ and ${ }^{13} \mathrm{C}$ NMR $(-7.3$ to $-8.7 \mathrm{ppm})$ spectra. Significantly, ${ }^{1} \mathrm{H}$ and ${ }^{13} \mathrm{C}$ NMR data of all complexes 8-pyr indicate a fast rotation of the distal aryl rings of the terphenyl-moieties given by the averaged signals for the $2^{\prime}, 6^{\prime}-$ and $3^{\prime}, 5^{\prime}-\mathrm{H}$ and carbon atoms, respectively. Similarly, an averaged signal is observed for the 3,5- $\mathrm{H}$, and the 2,6- and 3,5-carbon atoms of the central terphenyl aryl ring in each compound 8pyr (see Experimental Section for details). As exemplified for 8e-pyr a decoalescence of this dynamic behavior of the distal and central terphenyl aryl rings is not observed down to $223 \mathrm{~K}$ in methylene chloride- $d_{2}$.

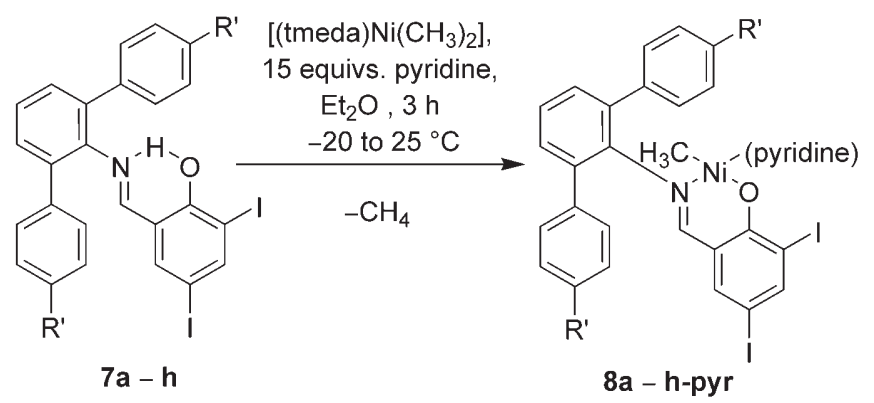

\begin{tabular}{cccccccc}
$\mathbf{a}$ & $\mathbf{b}$ & $\mathbf{c}$ & $\mathbf{d}$ & $\mathbf{e}$ & $\mathbf{f}$ & $\mathbf{g}$ & $\mathbf{h}$ \\
\hline $\mathrm{R}^{\prime} \mathrm{C}_{8} \mathrm{~F}_{17}$ & $\mathrm{CF}_{3}$ & $\mathrm{~F}$ & $\mathrm{H}$ & $\mathrm{Me}$ & $t-\mathrm{Bu}$ & $\mathrm{MeO}$ & $\mathrm{NMe}_{2}$
\end{tabular}

Scheme 1. Synthesis of complexes 8a-h-pyr.
Beyond this dynamic behavior within the terphenylmoieties, complexes 8-pyr in solution exist as a single isomer with respect to the stereochemistry of the nickel center in each case as concluded from their ${ }^{1} \mathrm{H}$ and ${ }^{13} \mathrm{C}$ NMR spectra. As an example, complex 8c-pyr was studied in more detail by NOEDIFF experiments in benzene- $d_{6}$ solution. These experiments indicate a trans-arrangement of the nickel-bound oxygen atom and methyl group as evidenced by a signal enhancement for the $2^{\prime}, 6^{\prime}$-protons on the terphenyl group after irradiation of the $\mathrm{Ni}-\mathrm{CH}_{3}$ signal. This trans-arrangement is in accordance with other data reported for $\left(\kappa^{2}-N, O\right)$ salicylaldiminato nickel alkyl/phenyl complexes in solution, ${ }^{[4 a, 16-18]}$ and underlines the stronger trans-effect exerted by the imine nitrogen when compared to the phenolic oxygen bound to nickel.

$\mathrm{X}$-Ray diffraction analysis of complex 8c-pyr confirms the trans-arrangement of oxygen $\mathrm{O} 1$ and the nickel bound methyl group $\mathrm{C} 1$ at the distorted square planar coordinated nickel center with bond distances to nickel in the expected range (Figure 2a).

The least root mean square (rms) deviation plane of the central terphenyl arene ring $\mathrm{C} 21-\mathrm{C} 26$ is twisted by $72.5(0.1)^{\circ}$ against the rms deviation plane defined by Ni1-O1-C12-C11-C10-N1, which causes the distal arene ring $\mathrm{C} 41-\mathrm{C} 46$ of the terphenyl substituent to be closer to the nickel center than the arene ring C31-C36. Consequently, a shorter $\mathrm{Ni}-\mathrm{F}$, and $\mathrm{Ni}-\mathrm{C}$ distance, respectively, is observed for Ni1-F2 (5.921) and Ni1-C44 (4.885 $\AA$ ) when compared to Ni1-F1 (7.103) and Ni1-C34 (6.003 $\mathrm{A})$ in the solid state structure.

As commonly accepted for late transition metal oligomerization/polymerization catalysts, the blocking of axial positions at the metal center retards chain transfer and favors polymerization over oligomerization, ${ }^{[2,3,8 \mathrm{dd}, e, 9]}$ although this effect has been demonstrated most clearly for cationic complexes. In this regard we note that F2 is placed in a nearly idealized axial position of the square planar coordinated nickel center (though far away by $5.921 \AA$, vide supra) (Figure 2b). The observed nickel-fluorine/nickel-C44 (C34) distances (vide supra) appear large enough, however, that F1, F2, C34, or C44 sterically do not interfere with the catalytically active nickel center when compared to $\mathrm{C} 42, \mathrm{C} 43, \mathrm{C} 45$, and $\mathrm{C} 46$ or to $\mathrm{C} 32, \mathrm{C} 33$, $\mathrm{C} 35$, and $\mathrm{C} 36$ [the closest distances are Ni1-C42 (3.820), N1-C46 (3.958 ̊)]. Since similar distances of the $4^{\prime}-\mathrm{R}^{\prime}$-substituents to the nickel center are expected for all complexes 8-pyr (and found in the solid state structure of 8d-pyr reported earlier) ${ }^{[16]}$ we conclude that the sterics of these substituents should exert a very minor influence on the catalytic properties of the nickel center and the polymer microstructures obtained with complexes 8-pyr. 

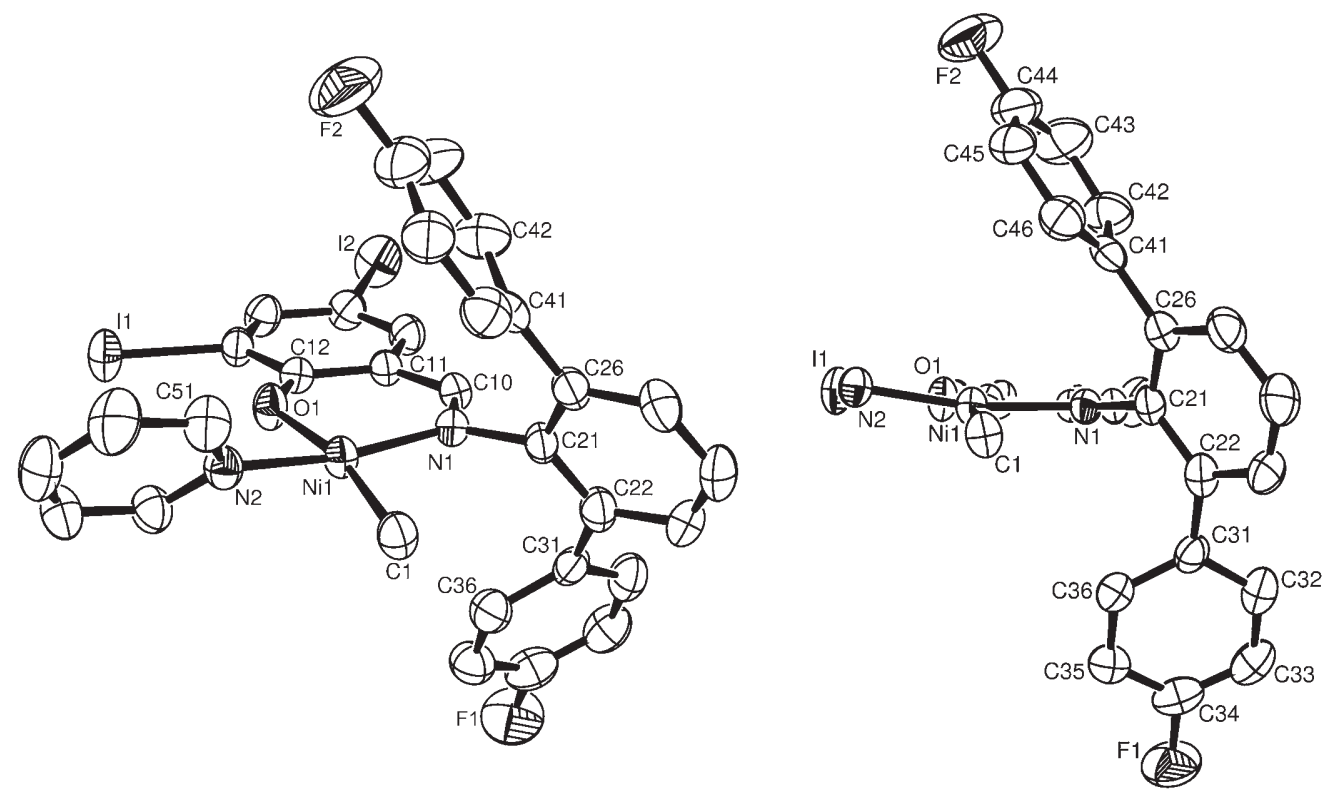

Figure 2. a (left) and b (right): X-Ray diffraction analysis of complex 8c-pyr with $50 \%$ probability ellipsoids. Hydrogen atoms and co-crystallized solvent molecules are omitted for clarity (a). Additionally, pyridine carbon atoms C51-C55 have been omitted in (b). Selected bond distances [̊̊] and angles [ $\left.{ }^{\circ}\right]$ : Ni1-O1 1.914(2), Ni1-C1 1.928(4), Ni1-N1 1.896(3), Ni1N2 1.911(3); O1-Ni1-N2 84.32(11), N2-Ni1-C1 88.59(14), C1-Ni1-N1 94.83(14), N1-Ni1-O1 93.86(11); O1-Ni1-N2-C51 -121.0(3), C10-N1-C21-C26 109.5(4), C21-C26-C41-C42 62.5(5), C21-C22-C31-C36 -49.1(6).

\section{Ethylene Polymerization/Oligomerization with Catalysts 8-pyr}

Complexes 8-pyr behave as single component ethylene polymerization catalysts. They were studied under a standard set of polymerization conditions (i.e., 40 bar ethylene, $50^{\circ} \mathrm{C}$ in $100 \mathrm{~mL}$ toluene, see Experimental Section for details). Table 1 summarizes the results of these polymerization runs and includes Hammett parameters $\sigma_{p}$ for the $\mathrm{R}^{\prime}$ substituents. ${ }^{[19]}$

While catalyst activity and lifetime were not in the focus of this study, we note that complexes 8-pyr are less active and decompose faster under the polymerization conditions employed than complexes 6-pyr. As evidenced by mass flow monitoring and polymer yields, half-life times for the catalytic activity of complexes 8a-g-pyr are estimated in the range of $1 \mathrm{~h}$ (8a,b-pyr) to $c a$. $25 \mathrm{~min}\left(\mathbf{8 f}, \mathbf{g}\right.$-pyr) at $50^{\circ} \mathrm{C}$. Even faster deactivation within less than $10 \mathrm{~min}$ was observed for complex 8h-pyr.

Under the polymerization conditions studied here, complexes 8a-h-pyr produce low molecular weight polyethylenes $\left(\mathrm{M}_{\mathrm{n}}: \quad 0.7-4.2 \times 10^{3} \mathrm{~g} \mathrm{~mol}^{-1}\right)$ with a narrow polydispersity of $c a$. 2-2.4 and variable degrees of branching. When correlated to Hammett parameters $\sigma_{\mathrm{p}}$ of their $\mathrm{R}^{\prime}$-substituent an increase in molecular weight is observed with increasing electron deficiency of $\mathrm{R}^{\prime}$, for example, $\mathrm{M}_{\mathrm{n}}(\mathbf{8 b}-\mathbf{p y r})=4.2 \times$ $10^{3} \mathrm{~g} \mathrm{~mol}^{-1}$ vs. $\mathrm{M}_{\mathrm{n}}(\mathbf{8 d - p y r})=2.9 \times 10^{3} \mathrm{~g} \mathrm{~mol}^{-1}$ vs. $\mathrm{M}_{\mathrm{n}}$ $(\mathbf{8 f}-\mathbf{p y r})=0.8 \times 10^{3} \mathrm{~g} \mathrm{~mol}^{-1} \quad$ (entries 2, 4, and 6 , Table 1). In contrast, sterically more demanding sub- stituents R' in complexes 8-pyr (e.g., tert-butyl vs. Me vs. H, entries 4-6, Table 1) do not increase the molecular weight as would be expected for a more efficient blocking of the axial positions at the nickel center. A similar correlation with electronic properties as found for the molecular weights is observed for the degree of branching of the polyethylenes obtained. Thus, electron-rich $\mathrm{R}^{\prime}$ groups result in more highly branched materials independent of the sterics of the $\mathrm{R}^{\prime}$ group [e.g., 70 branches $/ 1000$ carbon atoms obtained with complex 8f-pyr $\left(\mathrm{R}^{\prime}=\right.$ tert.-butyl) as compared to 30 branches $/ 1000$ carbon atoms obtained with complex 8b-pyr $\left(\mathrm{R}^{\prime}=\mathrm{CF}_{3}\right)$, entries 2 and 6 , Table 1]. A detailed analysis of the branching structure reveals that for electron-withdrawing $\mathrm{R}^{\prime}$ trace amounts of ethyl branches were observed ( $c a .1$ per 1000 carbon atoms $)$ in addition to $c a .22\left(\mathrm{R}^{\prime}=\mathrm{C}_{8} \mathrm{~F}_{17}\right)$ and ca. $29\left(\mathrm{R}^{\prime}=\mathrm{CF}_{3}\right)$ methyl branches per 1000 carbon atoms. More electron-rich $\mathrm{R}^{\prime}$ groups result in increasing numbers of ethyl and higher alkyl branches $\left(\mathrm{C}_{4}+\right)$ with increasing methyl branches, for example, ca., 5 ethyl, $4 \mathrm{C}_{4}+, 55$ methyl branches for $\mathrm{R}^{\prime}=\mathrm{MeO}$, ca. 7 ethyl, $8 \mathrm{C}_{4}+, 55$ methyl branches for $\mathrm{R}^{\prime}=$ tertbutyl, and $c a$. 14 ethyl, $18 \mathrm{C}_{4}+, 70$ methyl branches for $\mathrm{R}^{\prime}=\mathrm{NMe}_{2}$.

These findings as well as the analysis of the solid state structure of complex 8c-pyr (vide supra) underline that the electronic rather than the steric properties of the $\mathrm{R}^{\prime}$ substituents govern the ratio $k_{\text {chain growth }} /$ $k_{\text {chain transfer, }}$ and thus the molecular weight of the obtained polymers. In view of the flexible rotation 
Table 1. Polymerization results with complexes 8-pyr as catalyst precursors. ${ }^{[a]}$

\begin{tabular}{lllllllllll}
\hline & Complex 8 $\left(\mathrm{R}^{\prime}=\right)$ & $\sigma_{\mathrm{p}}{ }^{[\mathrm{b}]}$ & $\mathrm{n}[\mathbf{8}]^{[\mathrm{d}]}$ & $t^{[\mathrm{e}]}$ & Yield $^{[\mathrm{f}]}$ & $\mathrm{TON}^{[\mathrm{g}]}$ & $T_{m}{ }^{[\mathrm{h}]}$ & $B^{[\mathrm{j}]}$ & $\mathrm{M}_{\mathrm{n}}^{[\mathrm{k}]}$ & $\mathrm{M}_{\mathrm{w}} / \mathrm{M}_{\mathrm{n}}$ \\
\hline 1 & $\mathbf{a}\left(\mathrm{C}_{8} \mathrm{~F}_{17}\right)$ & $0.48^{[\mathrm{c}]}$ & 20 & 1 & 2.72 & 4.9 & 93 & 23 & 3.5 & 2.2 \\
2 & $\mathbf{b}\left(\mathrm{CF}_{3}\right)$ & 0.54 & 40 & 2 & 18.7 & 16.7 & 99 & 30 & 4.2 & 2.1 \\
3 & $\mathbf{c}(\mathrm{F})$ & 0.06 & 40 & 2 & 7.7 & 6.8 & 90 & 37 & 3.0 & 2.2 \\
4 & $\mathbf{d}(\mathrm{H})$ & 0 & 40 & 1 & 9.6 & 8.0 & 78 & 52 & 2.9 & 2.3 \\
5 & $\mathbf{e}(\mathrm{Me})$ & -0.17 & 40 & 1 & 2.6 & 2.3 & {$[\mathrm{i}]$} & 56 & 1.0 & 2.3 \\
6 & $\mathbf{f}(t \mathrm{Bu})$ & -0.20 & 20 & 1 & 2.31 & 4.1 & {$[\mathrm{i}]$} & 70 & 0.8 & 2.1 \\
7 & $\mathbf{g}(\mathrm{MeO})$ & -0.27 & 40 & 1 & 2.1 & 1.9 & {$[\mathrm{i}]$} & 64 & 0.9 & 2.4 \\
8 & $\mathbf{h}\left(\mathrm{NMe}_{2}\right)$ & -0.83 & 20 & 1 & 0.46 & 0.8 & {$[\mathrm{i}]$} & 102 & 0.7 & 2.3 \\
\hline
\end{tabular}

[a] Reaction conditions: $50^{\circ} \mathrm{C}, 40$ bar ethylene in $100 \mathrm{~mL}$ toluene.

[b] Hammett constants according to ref. ${ }^{[19]}$

[c] Value given for $\mathrm{CF}_{2} \mathrm{CF}_{2} \mathrm{CF}_{3}$ as the closest reported model for $\mathrm{C}_{8} \mathrm{~F}_{17}$.

[d] In $\mu$ mol.

[e] In hours.

[f] In g polyethylene.

[g] In $\left.10^{3} \mathrm{~mol}_{\left[\mathrm{C}_{2}\right.} \mathrm{H}_{4}\right] \times \mathrm{mol}[\mathbf{8}]^{-1}$.

[h] In ${ }^{\circ} \mathrm{C}$; values obtained from DSC second heating cycles.

[i] Amorphous polyethylene.

[j] Degree of branching (corrected for endgroups) in total branches (methyl, ethyl, and higher alkyl branches) per 1000 carbon atoms.

[k] In $10^{3} \mathrm{~g} \times \mathrm{mol}^{-1}$; determined by $\mathrm{GPC}$ at $160^{\circ} \mathrm{C}$ vs. linear polyethylene standards, confirmed by ${ }^{1} \mathrm{H}$ and ${ }^{13} \mathrm{C}$ NMR spectroscopy.

around the aryl-aryl and aryl $-\mathrm{N}=\mathrm{CH}$ bonds, and the possibility of in-plane rotation, it is in principle conceivable that the electronic nature of $\mathrm{R}^{\prime}$ influences the nickel coordinating nitrogen atom through the terphenyl moiety. As elucidated by Jenkins and Brookhart in detailed mechanistic studies for closely related neutral anilinotropone nickel polymerization catalysts, ${ }^{[20]}$ the barriers for $\beta$-hydride elimination $\left(\Delta G_{\beta \text {-elim }}^{+}=c a .17 .1 \mathrm{kcal} \mathrm{mol}^{-1}\right)$ and ethylene insertion
$\left(\Delta G^{+}{ }_{\text {ins }}=\right.$ ca. $\left.16-17 \mathrm{kcal} \mathrm{mol}^{-1}\right)$ are very similar (and likely higher than the barrier for trapping of agostic species, Scheme 2). Thus ethylene insertion (chain growth) and chain walking are clearly competing reactions with similar rates in the case of anilinotropone nickel catalysts. We assume that qualitatively the same holds true for neutral salicylaldiminato nickel methyl precatalysts 8-pyr, and that small relative changes in $\Delta G^{\neq}{ }_{\beta \text {-elim }}$ and $\Delta G^{+}{ }_{\text {ins }}$ exerted by the elec-

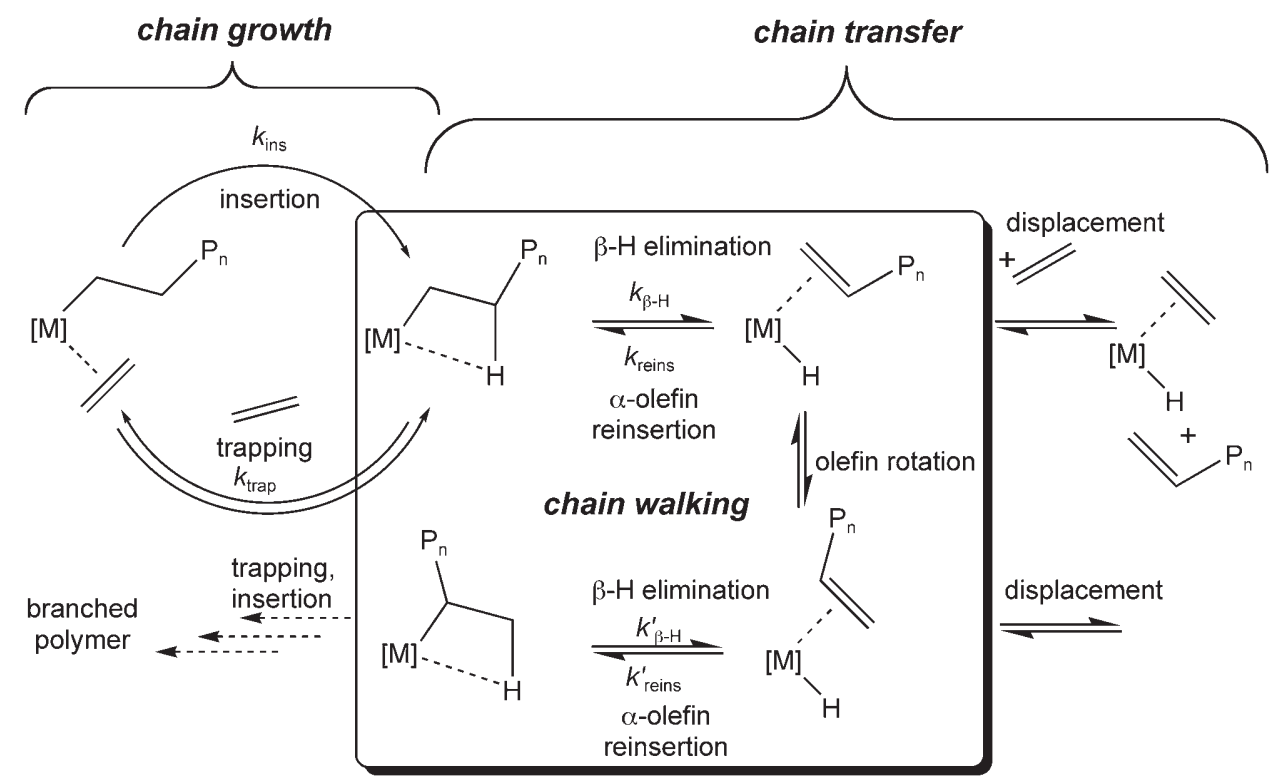

Scheme 2. General mechanistic scheme for late transition metal polymerization catalysts accounting for variable molecular weight and variable degrees of branching. 
tronics of the $\mathrm{R}^{\prime}$-substituents alter the ratio $\Delta G^{*}$ ins $\Delta G^{+}{ }_{\beta \text {-elim }}$ to a noticeable extent, resulting in different degrees of branching in the polyethylenes obtained.

\section{Conclusions}

The synthesis and ethylene polymerization behaviour of new $\left(k^{2}-N, O\right)$ salicylaldiminato nickel methyl pyridine complexes 8a-h-pyr bearing 2,6-di-(4- $\mathrm{R}^{\prime}$-phenyl)phenyl groups is reported. This class of complexes represents a rare example of polymerization catalysts allowing for a clear differentiation of steric and electronic effects of substituents which significantly alter polymer microstructures and material properties. A structure-reactivity relationship of these complexes based on the X-ray diffraction analysis of complex 8cpyr, as well as sterics and electronics of the $\mathrm{R}^{\prime}$ groups, indicates that the microstructures obtained with these complexes are controlled exclusively by the electronics rather than sterics of the $\mathrm{R}^{\prime}$ groups.

\section{Experimental Section}

\section{Genral Considerations}

All manipulations of air- and moisture-sensitive substances were carried out using standard Schlenk, vacuum, and glovebox techniques under argon or nitrogen. Pentane and dichloromethane- $d_{2}$ were distilled from calcium hydride, toluene from sodium, and diethyl ether from purple sodium benzophenone ketyl under argon prior to use. Benzene- $d_{6}$ was sonicated over finely dispersed sodium and distilled under argon prior to use. Pyridine was deoxygenated, distilled from potassium hydroxide, and stored in a Rotaflo flask prior to use. Petroleum ether (bp $55-85^{\circ} \mathrm{C}$ ) for column chromatography was distilled once by rotavap to remove high boiling impurities. 3,5-Diiodosalicylaldehyde was used as received from Aldrich. [(tmeda) $\mathrm{Ni}\left(\mathrm{CH}_{3}\right)_{2}$ ] was purchased from $\mathrm{MCat}$ and stored at $-30{ }^{\circ} \mathrm{C}$ in the glovebox prior to use. Complexes 8a,b-pyr ${ }^{[18 b]}$ and $\mathbf{8 d}^{[16]}$ were synthesized according to known procedures. 2,6-Diphenylaniline, 2,6-di-(4methoxyphenyl)aniline and 2,6-di-(4-tert-butylphenyl)aniline were reported by Rieger et al.,$^{[10]}$ and prepared in analogy to a procedure described by us. ${ }^{[16,17]}$ NMR spectra were recorded on a Varian Inova 400 instrument. ${ }^{1} \mathrm{H}$ chemical shifts were referenced to residual protiated solvent. The assignment of chemical shifts for new salicylaldimines and complexes 8-pyr is based on ${ }^{1} \mathrm{H}-,{ }^{1} \mathrm{H},{ }^{1} \mathrm{H}$-gCOSY, $\left\{{ }^{1} \mathrm{H}\right\}{ }^{13} \mathrm{C}-$, DEPT135-, ${ }^{1} \mathrm{H},{ }^{13} \mathrm{C}$-gHMQC, and ${ }^{1} \mathrm{H},{ }^{13} \mathrm{C}$-gHMBC NMR experiments. Elemental analyses were carried out at the Department of Chemistry at the University of Konstanz. Polymerization reactions were conducted in a $300-\mathrm{mL}$ Büchi miniclave equipped with a heating/cooling jacket supplied by a thermostat controlled by a thermocouple dipping into the polymerization mixture. Ethylene feeding of the autoclave was monitored by Bronkhorst mass-flow meters. Ethylene of 3.5 grade supplied by Gerling Holz + Co was used without further purification. Molecular weights of obtained polyethylenes were determined by ${ }^{1} \mathrm{H}$ and ${ }^{13} \mathrm{C}$ NMR spectroscopic analyses and GPC vs. linear polyethylene standards on a PL220 instrument equipped with mixed B columns using trichlorobenzene $/ 0.0125 \%$ BHT at $160{ }^{\circ} \mathrm{C}$. ${ }^{1} \mathrm{H}$ and ${ }^{13} \mathrm{C}$ NMR analyses of obtained polyethylenes were conducted in 1,1,2,2-tetrachloroethane- $d_{2}$ at $130^{\circ} \mathrm{C}$ in presence of $0.5 \mathrm{w} \% \mathrm{Cr}(\mathrm{acac})_{3}$ as a relaxation aid. Differential scanning calorimetry (DSC) of obtained polymers was performed on a Netzsch DSC $204 \mathrm{~F} 1$ with a heating/cooling rate of $10^{\circ} \mathrm{C}$ $\mathrm{min}^{-1}$. DSC data reported are from second heating cycles.

\section{General Procedure for the Preparation of Salicylaldimines $7 \mathbf{c}, \mathbf{e}-\mathbf{h}$}

To a mixture of $1.2 \mathrm{mmol}$ of diiodosalicylaldehyde, $1.2 \mathrm{mmol}$ of the respective terphenylamine, and $5 \mathrm{mg} p$-toluenesulfonic acid hydrate in a 50 -mL flask was added methanol (6$15 \mathrm{~mL}$ ). The suspension was heated to $60^{\circ} \mathrm{C}$ for $30-120 \mathrm{~min}$ while all starting materials dissolved, then sonicated at $25^{\circ} \mathrm{C}$ for $5 \mathrm{~min}$ to facilitate precipitation of the product, and stirred for $12-18 \mathrm{~h}$ at $25^{\circ} \mathrm{C}$. The resulting suspension was filtered, the residue washed with cold methanol $(3 \times 3 \mathrm{~mL}$, $\left.0^{\circ} \mathrm{C}\right)$ and dried under vacuum $\left(10^{-3} \mathrm{mbar}\right)$ to yield analytically pure samples.
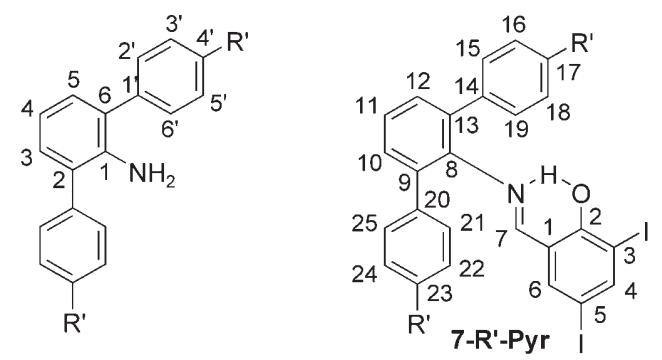

Salicylaldimine 7c $\left(\mathbf{R}^{\prime}=\mathbf{F}\right)$; a) 2,6-Di-(4-fluorophenyl)aniline: 2,6-Di-(4-fluorophenyl)aniline was prepared in analogy to ref. ${ }^{[16,17]}$ in $73 \%$ isolated yield. ${ }^{1} \mathrm{H}$ NMR $(300 \mathrm{MHz}$, $\left.\mathrm{CDCl}_{3}, 25^{\circ} \mathrm{C}\right): \delta=7.47\left(\mathrm{dd},{ }^{3} J_{\mathrm{H}, \mathrm{H}}=8.7 \mathrm{~Hz},{ }^{4} J_{\mathrm{H}, \mathrm{F}}=5.5 \mathrm{~Hz}, 4 \mathrm{H}\right.$, $2^{\prime}$ - and $\left.6^{\prime}-\mathrm{HH}\right), 7.15\left(\mathrm{dd},{ }^{3} J_{\mathrm{H}, \mathrm{H}}=8.7 \mathrm{~Hz},{ }^{3} J_{\mathrm{H}, \mathrm{F}}=8.7 \mathrm{~Hz}, 4 \mathrm{H}, 3^{\prime}-\right.$ and $\left.5^{\prime}-\mathrm{H}\right), 7.10\left(\mathrm{~d},{ }^{3} \mathrm{~J}_{\mathrm{H}, \mathrm{H}}=7.5 \mathrm{~Hz}, 2 \mathrm{H}, 3-\right.$ and $\left.5-\mathrm{H}\right) 6.88(\mathrm{t}$, $\left.{ }^{3} J_{\mathrm{H}, \mathrm{H}}=7.5 \mathrm{~Hz}, 1 \mathrm{H}, 4-\mathrm{H}\right), 3.75\left(\mathrm{br}, 2 \mathrm{H}, \mathrm{NH}_{2}\right) ;{ }^{13} \mathrm{C}\left\{{ }^{1} \mathrm{H}\right\} \mathrm{NMR}$ $\left(75.4 \mathrm{MHz}, \mathrm{CDCl}_{3}, 25^{\circ} \mathrm{C}\right): \delta=162.3\left(\mathrm{~d}, \mathrm{C}_{\mathrm{q}},{ }^{1} J_{\mathrm{C}, \mathrm{F}}=247 \mathrm{~Hz}\right.$, $\left.\mathrm{C}^{\prime}\right), 141.1\left(\mathrm{C}_{\mathrm{q}}, \mathrm{C} 1\right), 135.7\left(\mathrm{C}_{\mathrm{q}}, \mathrm{C1}^{\prime}\right), 131.2\left(\mathrm{CH}, \mathrm{C}^{\prime}\right.$ and $\left.\mathrm{C}^{\prime}\right), 130.1(\mathrm{CH}, \mathrm{C} 3$ and $\mathrm{C} 5), 127.2\left(\mathrm{C}_{\mathrm{q}}, \mathrm{C} 2\right.$ and $\left.\mathrm{C} 6\right), 118.4$ $(\mathrm{CH}, \mathrm{C} 4), 116.0\left(\mathrm{~d},{ }^{2} J_{\mathrm{C}, \mathrm{F}}=21.3 \mathrm{~Hz}, \mathrm{C} 3{ }^{\prime}\right.$ and $\left.\mathrm{C}^{\prime}\right)$; ${ }^{19} \mathrm{~F} \mathrm{NMR}$ (376.5 MHz, $\mathrm{CDCl}_{3}$, room temperature): $\delta=-115.3(\mathrm{~F})$.

b) Synthesis of Salicylaldimine 7c: Following the general procedure salicylaldimine 7c (yield: $697 \mathrm{mg}, 1.09 \mathrm{mmol}$, $91 \%$ ) was obtained from diiodosalicylaldehyde (449 mg) and 2,6-di-(4-fluorophenyl)aniline (338 mg) in methanol $(6 \mathrm{~mL}) .{ }^{1} \mathrm{H}$ NMR $\left(399.8 \mathrm{MHz}, \mathrm{C}_{6} \mathrm{D}_{6}, 25^{\circ} \mathrm{C}\right): \delta=13.60(\mathrm{~s}, 1 \mathrm{H}$, $\mathrm{OH}), 7.74\left(\mathrm{~d},{ }^{4} J_{\mathrm{H}, \mathrm{H}}=1.7 \mathrm{~Hz}, 1 \mathrm{H}, 4-\mathrm{H}\right), 7.12(\mathrm{~s}, 1 \mathrm{H}, 7-\mathrm{H})$, $7.08(\mathrm{~m}, 2 \mathrm{H}, 10-$ and $12-\mathrm{H}), 7.01$ and 7.00 (m, 5 H, 16-, 18-, 22-, 24-, and 11-H), 6.68 (m, 5H, 6-, 15-, 19-, 21-, and 25-H); ${ }^{13} \mathrm{C}\left\{{ }^{1} \mathrm{H}\right\}$ NMR $\left(100.5 \mathrm{MHz}, \mathrm{C}_{6} \mathrm{D}_{6}, 25^{\circ} \mathrm{C}\right): \delta=167.2(\mathrm{CH}, \mathrm{C} 7)$, $162.3\left(\mathrm{C}_{\mathrm{q}}, \mathrm{d},{ }^{1} J_{\mathrm{C}, \mathrm{F}}=247 \mathrm{~Hz}, \mathrm{C} 17\right.$ and $\left.\mathrm{C} 23\right), 160.2\left(\mathrm{C}_{\mathrm{q}}, \mathrm{C} 2\right)$, 149.7 (CH, C4), $144.7\left(\mathrm{C}_{\mathrm{q}}, \mathrm{C} 8\right), 140.2(\mathrm{CH}, \mathrm{C} 6), 135.2\left(\mathrm{C}_{\mathrm{q}}, \mathrm{d}\right.$, ${ }^{4} J_{\mathrm{CF}}=3 \mathrm{~Hz}, \mathrm{C} 14$ and $\left.\mathrm{C} 20\right), 134.2\left(\mathrm{C}_{\mathrm{q}}, \mathrm{C} 9\right.$ and $\left.\mathrm{C} 13\right), 131.5$ $\left(\mathrm{CH}, \mathrm{d},{ }^{3} J_{\mathrm{C}, \mathrm{F}}=8 \mathrm{~Hz}, \mathrm{C} 15, \mathrm{C} 19, \mathrm{C} 21\right.$, and $\left.\mathrm{C} 25\right), 130.6(\mathrm{CH}$, 
$\mathrm{C} 10$ and $\mathrm{C} 12), 126.5(\mathrm{CH}, \mathrm{C} 11), 120.1\left(\mathrm{C}_{\mathrm{q}}, \mathrm{C} 1\right), 115.7(\mathrm{CH}$, $\mathrm{d},{ }^{2} J_{\mathrm{C}, \mathrm{F}}=21 \mathrm{~Hz}, \mathrm{C} 16, \mathrm{C} 18, \mathrm{C} 22$, and C24), $87.6\left(\mathrm{C}_{\mathrm{q}}, \mathrm{C} 3\right), 80.4$ $\left(\mathrm{C}_{\mathrm{q}}, \mathrm{C} 5\right)$; anal. calcd. for $\mathrm{C}_{25} \mathrm{H}_{15} \mathrm{NOF}_{2} \mathrm{I}_{2}\left(737.21 \mathrm{~g} \mathrm{~mol}^{-1}\right)$ : $\mathrm{C}$ 47.12, H 2.37, N 2.20; found: C 47.65, H 2.67, N 1.89.

Salicylaldimine 7e $\left(\mathbf{R}^{\prime}=\mathrm{Me}\right)$; a) 2,6-Di-(4-methylphenyl)aniline: 2,6-Di-(4-methyl-phenyl)aniline was prepared in analogy to ref. ${ }^{[16,17]}$ in $76 \%$ isolated yield. ${ }^{1} \mathrm{H}$ NMR $\left(399.8 \mathrm{MHz}, \mathrm{CDCl}_{3}, 25^{\circ} \mathrm{C}\right): \delta=7.38\left(\mathrm{~d},{ }^{3} J_{\mathrm{H}, \mathrm{H}}=8.0 \mathrm{~Hz}, 4 \mathrm{H}\right.$, $2^{\prime}$ - and $\left.6^{\prime}-\mathrm{H}\right), 7.23\left(\mathrm{~d},{ }^{3} J_{\mathrm{H}, \mathrm{H}}=8.0 \mathrm{~Hz}, 4 \mathrm{H}, 3^{\prime}-\right.$ and $\left.5^{\prime}-\mathrm{H}\right), 7.08$ $\left(\mathrm{d},{ }^{3} J_{\mathrm{H}, \mathrm{H}}=7.6 \mathrm{~Hz}, 2 \mathrm{H}, 3-\right.$ and $\left.5-\mathrm{H}\right), 6.85\left(\mathrm{t},{ }^{3} J_{\mathrm{H}, \mathrm{H}}=7.6 \mathrm{~Hz}\right.$, $1 \mathrm{H}, 4-\mathrm{H}), 3.89$ (br, $\left.2 \mathrm{H}, \mathrm{NH}_{2}\right), 2.37\left(\mathrm{~s}, 6 \mathrm{H}, 2 \times p-\mathrm{CH}_{3}\right)$; ${ }^{13} \mathrm{C}\left({ }^{1} \mathrm{H}\right\}$ NMR $\left(100.5 \mathrm{MHz}, \mathrm{CDCl}_{3}, 25^{\circ} \mathrm{C}\right): \delta=140.3\left(\mathrm{C}_{\mathrm{q}}, \mathrm{C} 1\right)$, $137.2\left(\mathrm{C}_{\mathrm{q}}, \mathrm{C}^{\prime}\right), 136.8\left(\mathrm{C}_{\mathrm{q}}, \mathrm{C}^{\prime}\right), 129.8(\mathrm{CH}, \mathrm{C} 3$ and $\mathrm{C} 5)$, 129.7 and $129.4\left(\mathrm{CH}\right.$ each, $\mathrm{C}^{\prime}, \mathrm{C}^{\prime}, \mathrm{C5}^{\prime}$, and $\left.\mathrm{C}^{\prime}\right), 128.5\left(\mathrm{C}_{\mathrm{q}}\right.$, 9-, and $\mathrm{C} 2$ and $\mathrm{C} 6), 118.8(\mathrm{CH}, \mathrm{C} 4), 21.4\left(\mathrm{CH}_{3}, 2 \times p-\mathrm{CH}_{3}\right)$; anal. calcd. for $\mathrm{C}_{20} \mathrm{H}_{19} \mathrm{~N}\left(273.02 \mathrm{~g} \mathrm{~mol}^{-1}\right)$ : $\mathrm{C} 87.99, \mathrm{H} 7.01, \mathrm{~N}$ 5.13; found: C 87.20, H 7.16, N 5.15.

b) Synthesis of Salicylaldimine 7e: Following the general procedure salicylaldimine 7e (yield: $669 \mathrm{mg}, 1.06 \mathrm{mmol}$, $89 \%$ ) was obtained from diiodosalicylaldehyde (449 mg) and 2,6-di-(4-methylphenyl)aniline $(328 \mathrm{mg})$ in methanol $(15 \mathrm{~mL}) .{ }^{1} \mathrm{H}$ NMR $\left(399.8 \mathrm{MHz}, \mathrm{C}_{6} \mathrm{D}_{6}, 25^{\circ} \mathrm{C}\right): \delta=13.92$ (s br., $\mathrm{OH}), 7.68\left(\mathrm{~d},{ }^{4} J_{\mathrm{H}, \mathrm{H}}=1.8 \mathrm{~Hz}, 1 \mathrm{H}, 4-\mathrm{H}\right), 7.27\left(\mathrm{~d},{ }^{3} J_{\mathrm{H}, \mathrm{H}}=\right.$ $7.6 \mathrm{~Hz}, 2 \mathrm{H}, 10-$ and $12-\mathrm{H}), 7.26(\mathrm{~s}, 1 \mathrm{H}, 7-\mathrm{H}), 7.21(\mathrm{vd}, J=$ $8.0 \mathrm{~Hz}, 4 \mathrm{H}, 15-, 19-, 21-$, and $25-\mathrm{H}), 7.09\left(\mathrm{t},{ }^{3} J_{\mathrm{H}, \mathrm{H}}=7.6 \mathrm{~Hz}\right.$, $11-\mathrm{H}), 6.89(\mathrm{vd}, J=8.0 \mathrm{~Hz}, 4 \mathrm{H}, 16-, 18-, 22-$, and $24-\mathrm{H}), 6.65$ $\left(\mathrm{d},{ }^{4} J_{\mathrm{H}, \mathrm{H}}=1.8 \mathrm{~Hz}, 1 \mathrm{H}, 6-\mathrm{H}\right), 1.96\left(\mathrm{~s}, 6 \mathrm{H}, 2 \times p-\mathrm{CH}_{3}\right) ;{ }^{13} \mathrm{C}\left\{{ }^{1} \mathrm{H}\right\}$ $\operatorname{NMR}\left(100.5 \mathrm{MHz}, \mathrm{C}_{6} \mathrm{D}_{6}, 25^{\circ} \mathrm{C}\right): \delta=166.9(\mathrm{CH}, \mathrm{C} 7), 160.4$ $\left(\mathrm{C}_{\mathrm{q}}, \mathrm{C} 2\right), 149.3(\mathrm{CH}, \mathrm{C} 4), 145.0\left(\mathrm{C}_{\mathrm{q}}, \mathrm{C} 8\right), 140.2(\mathrm{CH}, \mathrm{C} 6)$, $137.0\left(\mathrm{C}_{\mathrm{q}}, \mathrm{C} 17\right.$ and $\left.\mathrm{C} 23\right), 136.6$ and $135.3\left(\mathrm{C}_{\mathrm{q}}\right.$ each, $\mathrm{C} 9, \mathrm{C} 13$, $\mathrm{C} 14$, and $\mathrm{C} 20), 130.4(\mathrm{CH}, \mathrm{C} 10$ and $\mathrm{C} 12), 129.8(\mathrm{CH}, \mathrm{C} 15$, $\mathrm{C} 19, \mathrm{C} 21$, and $\mathrm{C} 25), 129.5(\mathrm{CH}, \mathrm{C} 16, \mathrm{C} 18, \mathrm{C} 22$, and $\mathrm{C} 24)$, $126.5(\mathrm{CH}, \mathrm{C} 11), 120.4\left(\mathrm{C}_{\mathrm{q}}, \mathrm{C} 1\right), 87.6$ and $80.2\left(\mathrm{C}_{\mathrm{q}}\right.$ each, $\mathrm{C} 3$ and C5), $20.9\left(\mathrm{CH}_{3}, 2 \times p-\mathrm{CH}_{3}\right)$; anal. calcd. for $\mathrm{C}_{27} \mathrm{H}_{21} \mathrm{NOI}_{2}$ $\left(629.27 \mathrm{~g} \mathrm{~mol}^{-1}\right)$ : C 51.53, H 3.36, N 2.23; found: C 51.94, H 3.67, N 2.01.

Salicylaldimine $7 \mathbf{f}\left(\mathbf{R}^{\prime}=\boldsymbol{t}\right.$-Bu): Following the general procedure salicylaldimine $7 f$ (yield: $745 \mathrm{mg}, 1.05 \mathrm{mmol}, 87 \%$ ) was obtained from diiodosalicylaldehyde $(449 \mathrm{mg})$ and 2,6di-(4-tert.-butylphenyl)aniline $(429 \mathrm{mg})$ in methanol $(10 \mathrm{~mL}) .{ }^{1} \mathrm{H}$ NMR $\left(399.8 \mathrm{MHz}, \mathrm{C}_{6} \mathrm{D}_{6}, 25^{\circ} \mathrm{C}\right): \delta=13.79$ (s br., $\mathrm{OH}), 7.69\left(\mathrm{~d},{ }^{4} J_{\mathrm{H}, \mathrm{H}}=1.7 \mathrm{~Hz}, 1 \mathrm{H}, 4-\mathrm{H}\right), 7.33\left(\mathrm{~d},{ }^{3} J_{\mathrm{H}, \mathrm{H}}=\right.$ $7.6 \mathrm{~Hz}, 2 \mathrm{H}, 10-$ and $12-\mathrm{H}), 7.29(\mathrm{vd}, J=7.7 \mathrm{~Hz}, 4 \mathrm{H}, 15-, 19-$, 21-, and 25-H), $7.26(\mathrm{~s}, 1 \mathrm{H}, 7-\mathrm{H}), 7.21(\mathrm{vd}, J=7.7 \mathrm{~Hz}, 4 \mathrm{H}$, $16-, 18-, 22-$, and $24-\mathrm{H}), 7.11\left(\mathrm{t},{ }^{3} J_{\mathrm{H}, \mathrm{H}}=7.6 \mathrm{~Hz}, 1 \mathrm{H}, 11-\mathrm{H}\right)$, $6.53\left(\mathrm{~d},{ }^{4} J_{\mathrm{H}, \mathrm{H}}=1.7 \mathrm{~Hz}, 1 \mathrm{H}, 6-\mathrm{H}\right), 1.16(\mathrm{~s}, 18 \mathrm{H}, 2 \times t-\mathrm{Bu})$; ${ }^{13} \mathrm{C}\left\{{ }^{1} \mathrm{H}\right\}$ NMR $\left(100.5 \mathrm{MHz}, \mathrm{C}_{6} \mathrm{D}_{6}, 25^{\circ} \mathrm{C}\right): \delta=166.8(\mathrm{CH}, \mathrm{C} 7)$, $160.3\left(\mathrm{C}_{\mathrm{q}}, \mathrm{C} 2\right), 150.3\left(\mathrm{C}_{\mathrm{q}}, \mathrm{C} 17\right.$ and $\left.\mathrm{C} 23\right), 149.1(\mathrm{CH}, \mathrm{C} 4)$, $144.8\left(\mathrm{C}_{\mathrm{q}}, \mathrm{C} 8\right), 140.1(\mathrm{CH}, \mathrm{C} 6), 136.8$ and $135.6\left(\mathrm{C}_{\mathrm{q}}\right.$ each, C9, C13, C14, and $\mathrm{C} 20), 130.3(\mathrm{CH}, \mathrm{C} 10$ and $\mathrm{C} 12), 129.8$ (CH, C15, C19, C21, and C25), 126.7 (CH, C16, C18, C22, and $\mathrm{C} 24), 120.6\left(\mathrm{C}_{\mathrm{q}}, \mathrm{C} 1\right), 87.5$ and $79.7\left(\mathrm{C}_{\mathrm{q}}\right.$ each, $\mathrm{C} 3$ and C5), $34.5\left(\mathrm{C}_{\mathrm{g}}, 2 \times t-\mathrm{Bu}\right), 31.3\left(\mathrm{CH}_{3}, 2 \times t\right.$-Bu $)$; anal. calcd. for $\mathrm{C}_{33} \mathrm{H}_{32} \mathrm{NOI}_{2}\left(713.43 \mathrm{~g} \mathrm{~mol}^{-1}\right)$ : C 55.56, H 4.66, N 1.96; found: C 55.95, H 5.00, N 1.63.

Salicylaldimine $7 \mathbf{g}\left(\mathbf{R}^{\prime}=\mathbf{M e O}\right)$ : Following the general procedure salicylaldimine $\mathbf{7 g}$ (yield: $671 \mathrm{mg}, 1.01 \mathrm{mmol}, 85 \%$ ) was obtained from diiodosalicylaldehyde $(449 \mathrm{mg})$ and 2,6di-(4-methoxyphenyl)aniline $(366 \mathrm{mg})$ in methanol $(10 \mathrm{~mL})$. ${ }^{1} \mathrm{H}$ NMR $\left(399.8 \mathrm{MHz}, \mathrm{C}_{6} \mathrm{D}_{6}, 25^{\circ} \mathrm{C}\right): \delta=14.05(\mathrm{~s}, 1 \mathrm{H}, \mathrm{OH})$, $7.71\left(\mathrm{~d},{ }^{4} J_{\mathrm{H}, \mathrm{H}}=1.7 \mathrm{~Hz}, 1 \mathrm{H}, 4-\mathrm{H}\right), 7.32(\mathrm{~s}, 1 \mathrm{H}, 7-\mathrm{H}), 7.26(\mathrm{~d}$, ${ }^{3} J_{\mathrm{H}, \mathrm{H}}=7.6 \mathrm{~Hz}, 2 \mathrm{H}, 10-$ and $\left.12-\mathrm{H}\right), 7.22(\mathrm{vd}, J=7.6 \mathrm{~Hz}, 4 \mathrm{H}$,
15-, 19-, 21-, and 25-H), $7.11\left(\mathrm{t},{ }^{3} J_{\mathrm{H} H}=7.6 \mathrm{~Hz}, 1 \mathrm{H}, 11-\mathrm{H}\right)$, $6.69(\mathrm{~m}, 5 \mathrm{H}, 16-, 18-, 22-, 24-$, and $6-\mathrm{H}), 3.18(\mathrm{~s}, 6 \mathrm{H}, 2 \times$ $\left.\mathrm{OCH}_{3}\right) ;{ }^{13} \mathrm{C}\left\{{ }^{1} \mathrm{H}\right\}$ NMR $\left(100.5 \mathrm{MHz}, \mathrm{C}_{6} \mathrm{D}_{6}, 25^{\circ} \mathrm{C}\right): \delta=166.9$ $(\mathrm{CH}, \mathrm{C} 7), 160.4\left(\mathrm{C}_{\mathrm{q}}, \mathrm{C} 2\right), 159.3\left(\mathrm{C}_{\mathrm{q}}, \mathrm{C} 17\right.$ and $\left.\mathrm{C} 23\right), 149.3$ $(\mathrm{CH}, \mathrm{C} 4), 144.9\left(\mathrm{C}_{\mathrm{q}}, \mathrm{C} 8\right), 140.3(\mathrm{CH}, \mathrm{C} 6), 135.0$ and 131.7 $\left(\mathrm{C}_{\mathrm{q}}\right.$ each, $\mathrm{C} 9, \mathrm{C} 13, \mathrm{C} 14$, and $\left.\mathrm{C} 20\right), 131.1(\mathrm{CH}, \mathrm{C} 15, \mathrm{C} 19$, $\mathrm{C} 21$, and $\mathrm{C} 25), 130.2(\mathrm{CH}, \mathrm{C} 10$ and $\mathrm{C} 12), 126.6(\mathrm{CH}, \mathrm{C} 11)$, $120.5\left(\mathrm{C}_{\mathrm{q}}, \mathrm{C} 1\right), 114.3(\mathrm{CH}, \mathrm{C} 16, \mathrm{C} 18, \mathrm{C} 22$, and $\mathrm{C} 24), 87.6$ $\left(\mathrm{C}_{\mathrm{q}}, \mathrm{C} 3\right), 80.2\left(\mathrm{C}_{\mathrm{q}}, \mathrm{C} 5\right), 54.7\left(\mathrm{CH}_{3}, 2 \times \mathrm{OCH}_{3}\right)$; anal. calcd. for $\mathrm{C}_{27} \mathrm{H}_{21} \mathrm{NO}_{3} \mathrm{I}_{2}\left(661.27 \mathrm{~g} \mathrm{~mol}^{-1}\right): \mathrm{C} 49.04, \mathrm{H} 3.20, \mathrm{~N} 2.12$; found: C 49.33, H 3.87, N 1.97 .

Salicylaldimine 7h $\left(\mathbf{R}^{\prime}=\mathrm{NMe}_{2}\right)$; a) 2,6-Di-(4-dimethylaminophenyl)aniline: To a mixture of 2,6-dibromoaniline (1.004 g, $4 \mathrm{mmol}), \quad 4$-dimethylaminophenylboronic acid $(1.518 \mathrm{~g}, 9.2 \mathrm{mmol}), \mathrm{Pd}(\mathrm{dba})_{2},(23 \mathrm{mg}, 41 \mu \mathrm{mol})$, and $\mathrm{PPh}_{3}$, $(22.6 \mathrm{mg}, 86 \mu \mathrm{mol})$ in an argon-filled Schlenk tube was added toluene $(14 \mathrm{~mL})$. The resulting purple suspension was stirred for $c a$. $15 \mathrm{~min}$ until the color changed to orange. Then ethanol/water $(1: 1,5 \mathrm{~mL})$ and $\mathrm{Na}_{2} \mathrm{CO}_{3}(1.70 \mathrm{~g}$, $16 \mathrm{mmol}$ ) were added and the mixture was stirred for $48 \mathrm{~h}$ at $95^{\circ} \mathrm{C}$. The resulting biphasic mixture was allowed to cool to $25^{\circ} \mathrm{C}$, stirred for $30-60 \mathrm{~min}$ under air (resulting in formation of palladium black), and poured into a separatory funnel. Water and diethyl ether were added until all salts and organic material dissolved. The organic layer was separated (and filtered through a plug of celite to remove $\mathrm{Pd}$ black), the aqueous phase extracted with additional diethyl ether $(2 \times 25 \mathrm{~mL})$, and the combined organic phases concentrated under reduced pressure $\left(35^{\circ} \mathrm{C}, 650 \mathrm{mbar}\right.$, then 20 mbar). Analytically pure 2,6-di-(4-dimethylaminopheny1)aniline was obtained after column chromatography of the residue on silica (Merck silica gel 60. TLC: Merck silica gel $60 \mathrm{~F}_{254}$ plates; $R_{\mathrm{f}}$-values refer to TLC tests) using petroleum ether/toluene $\left(30: 1, \quad R_{\mathrm{f}}=0.2\right)$ as eluent; yield: $1.147 \mathrm{~g}$ (3.46 mmol, $87 \%$ ). ${ }^{1} \mathrm{H}$ NMR $\left(399.8 \mathrm{MHz}, \mathrm{CDCl}_{3}, 25^{\circ} \mathrm{C}\right): \delta=$ $7.45(\mathrm{vd}, J=8.0 \mathrm{~Hz}, 4 \mathrm{H}, 2 \times 9-$ and $11-\mathrm{H}), 7.20\left(\mathrm{~d},{ }^{3} J_{\mathrm{H}, \mathrm{H}}=\right.$ $7.6 \mathrm{~Hz}, 2 \mathrm{H}, 3-$ and $5-\mathrm{H}), 6.86(\mathrm{~m}, 5 \mathrm{H}, 2 \times 8-$ and $12-\mathrm{H}$ and $4-$ $\mathrm{H}), 3.92$ (s br., $2 \mathrm{H}, \mathrm{NH}_{2}$ ), $3.03\left[\mathrm{~s}, 12 \mathrm{H}, 2 \times \mathrm{N}\left(\mathrm{CH}_{3}\right)_{2}\right] ;{ }^{13} \mathrm{C}\left\{{ }^{1} \mathrm{H}\right\}$ NMR $\left(100.5 \mathrm{MHz}, \mathrm{CDCl}_{3}, 25^{\circ} \mathrm{C}\right): \delta=149.6\left(\mathrm{C}_{\mathrm{q}}, 2 \times \mathrm{C} 10\right)$, $141.4(\mathrm{Cq}, \mathrm{C} 1), 130.0(\mathrm{CH}, 2 \times \mathrm{C} 8$ and $\mathrm{C} 12), 129.0(\mathrm{CH}, \mathrm{C} 3$ and $\mathrm{C} 5), 128.0$ and $127.8\left(\mathrm{C}_{\mathrm{q}}\right.$ each, $\mathrm{C} 6$ and $\left.2 \times \mathrm{C} 7\right), 118.0$ $(\mathrm{CH}, \mathrm{C} 4), 112.7(\mathrm{CH}, 2 \times \mathrm{C} 9$ and $\mathrm{C} 11), 40.6\left[\mathrm{CH}_{3}, 2 \times \mathrm{N}-\right.$ $\left.\left(\mathrm{CH}_{3}\right)_{2}\right]$; anal. calcd. for $\mathrm{C}_{22} \mathrm{H}_{25} \mathrm{~N}_{3}\left(331.45 \mathrm{~g} \mathrm{~mol}^{-1}\right)$ : C 79.72, H 7.60, N 12.68; found: C 80.01, H 7.31, N 12.48.

b) Synthesis of Salicylaldimine 7h: Following the general procedure salicylaldimine $\mathbf{7 h}$ (yield: $718 \mathrm{mg}, 1.04 \mathrm{mmol}$, $87 \%$ ) was obtained from diiodosalicylaldehyde (449 mg) and 2,6-di(4-dimethylaminophenyl)aniline $(398 \mathrm{mg})$ in methanol $(10 \mathrm{~mL}) .{ }^{1} \mathrm{H}$ NMR $\left(399.8 \mathrm{MHz}, \mathrm{CDCl}_{3}, 25^{\circ} \mathrm{C}\right): \delta=14.03$ (s br., $1 \mathrm{H}, \mathrm{OH}), 7.98\left(\mathrm{~d},{ }^{4} J_{\mathrm{H}, \mathrm{H}}=2.0 \mathrm{~Hz}, 1 \mathrm{H}, 4-\mathrm{H}\right), 7.83$ (s, $1 \mathrm{H}, 7-\mathrm{H}), 7.33(\mathrm{~m}, 3 \mathrm{H}, 10-12-\mathrm{H}), 7.23(\mathrm{vd}, J=8.8 \mathrm{~Hz}, 4 \mathrm{H}$, 15-, 19-, 21-, and 25-H), $7.13\left(\mathrm{~d},{ }^{4} J_{\mathrm{H}, \mathrm{H}}=2.0 \mathrm{~Hz}, 1 \mathrm{H}, 6-\mathrm{H}\right)$, 6.72 (vd br., $J=8.8 \mathrm{~Hz}, 4 \mathrm{H}, 16-, 18-, 22-$, and $24-\mathrm{H}$ ), 2.96 [s, $\left.12 \mathrm{H}, 2 \times \mathrm{N}\left(\mathrm{CH}_{3}\right)_{2}\right] ;{ }^{13} \mathrm{C}\left\{{ }^{1} \mathrm{H}\right\} \quad \mathrm{NMR} \quad\left(100.5 \mathrm{MHz}, \mathrm{CDCl}_{3}\right.$, $\left.25^{\circ} \mathrm{C}\right): \delta=166.0(\mathrm{CH}, \mathrm{C} 7), 160.3\left(\mathrm{C}_{\mathrm{q}}, \mathrm{C} 2\right), 149.4\left(\mathrm{C}_{\mathrm{q}}\right.$ br., $\mathrm{C} 17$ and $\mathrm{C} 23), 148.7(\mathrm{CH}, \mathrm{C} 4), 143.8\left(\mathrm{C}_{\mathrm{q}}, \mathrm{C} 8\right), 140.2(\mathrm{CH}, \mathrm{C} 6)$, $135.0\left(\mathrm{C}_{\mathrm{q}}, \mathrm{C} 9, \mathrm{C} 13, \mathrm{C} 14\right.$, and $\left.\mathrm{C} 20\right), 130.4(\mathrm{CH}, \mathrm{C} 15, \mathrm{C} 19$, $\mathrm{C} 21$, and $\mathrm{C} 25), 129.4(\mathrm{CH}, \mathrm{C} 10$ and $\mathrm{C} 12), 126.3(\mathrm{CH}, \mathrm{C} 11)$, $120.5\left(\mathrm{C}_{\mathrm{q}}, \mathrm{C} 1\right), 112.5$ (CH br., $\mathrm{C} 16, \mathrm{C} 18, \mathrm{C} 22$, and $\left.\mathrm{C} 24\right), 87.1$ $\left(\mathrm{C}_{\mathrm{q}}, \mathrm{C} 3\right), 79.2\left(\mathrm{C}_{\mathrm{q}}, \mathrm{C} 5\right), 40.6\left[\mathrm{CH}_{3}, 2 \times \mathrm{N}\left(\mathrm{CH}_{3}\right)_{2}\right]$; anal. calcd. for $\mathrm{C}_{29} \mathrm{H}_{27} \mathrm{~N}_{3} \mathrm{OI}_{2}\left(687.35 \mathrm{~g} \mathrm{~mol}^{-1}\right)$ : C 50.67, H 3.96, $\mathrm{N} 6.11$; found: C 50.77, H 3.88, N 6.00 . 


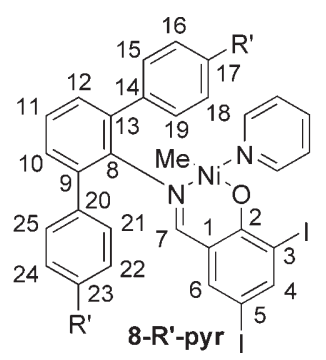

\section{General Procedure for the Synthesis of $\left(\kappa^{2}-N, O\right)$ - Salicylaldiminato Nickel Methylpyridine Complexes 8-pyr}

To [(tmeda) $\left.\mathrm{Ni}\left(\mathrm{CH}_{3}\right)_{2}\right](40.8 \mathrm{mg}, 200 \mu \mathrm{mol})$ and the respective salicylaldimine $\mathbf{7 a - h}(200 \mu \mathrm{mol})$ in a $10-\mathrm{mL}$ septumcapped Schlenk tube was added a solution of pyridine $(240 \mathrm{mg}, 3.04 \mathrm{mmol})$ in diethyl ether $(12 \mathrm{~mL})$ at $-20^{\circ} \mathrm{C}$. The resulting orange to red solution was stirred for $60 \mathrm{~min}$ at $-20^{\circ} \mathrm{C}$, the solution was allowed to warm to $0^{\circ} \mathrm{C}$ and stirred for additional $2 \mathrm{~h}$. The solvent was then removed under high vacuum $\left(10^{-3} \mathrm{mbar}\right)$. The resulting solid was transferred to a Schlenk frit, washed with pentane $(4 \times 2 \mathrm{~mL})$ and dried under high vacuum $\left(10^{-3}\right.$ mbar $)$ to yield pyridine complexes 8-pyr.

Complex 8c-pyr $\left(\mathbf{R}^{\prime}=\mathbf{F}\right)$ : Following the general procedure complex 8c-pyr was obtained from [(tmeda) $\left.\mathrm{Ni}\left(\mathrm{CH}_{3}\right)_{2}\right]$ (40.8 mg, $200 \mu \mathrm{mol})$, salicylaldimine $7 \mathbf{c}(127.4 \mathrm{mg}, 200 \mu \mathrm{mol})$ and pyridine $(240 \mathrm{mg}, 3.04 \mathrm{mmol})$ as an orange-red powder; yield: $121.2 \mathrm{mg}(153.6 \mu \mathrm{mol}, 77 \%) .{ }^{1} \mathrm{H} \mathrm{NMR}(399.8 \mathrm{MHz}$, $\mathrm{C}_{6} \mathrm{D}_{6}, 25^{\circ} \mathrm{C}$ ): $\delta=8.28$ (m br., $2 \mathrm{H}, o-\mathrm{H}$ pyridine), 7.97 (d, $\left.{ }^{4} J_{\mathrm{H}, \mathrm{H}}=2.0 \mathrm{~Hz}, 1 \mathrm{H}, 4-\mathrm{H}\right), 7.48(\mathrm{~m}, 4 \mathrm{H}, 15-, 19-, 21-$, and $25-$ $\mathrm{H}), 7.04(\mathrm{~m}, 2 \mathrm{H}, 10-$ and $12-\mathrm{H}), 6.98(\mathrm{~m}, 2 \mathrm{H}, 11-\mathrm{H}$ and $p-\mathrm{H}$ pyridine), 6.92 (s, 1H, 7-H), 6.87 (m, 5H, 6-, 16-, 18-, 22-, and $24-\mathrm{H}), 6.30$ (m br., $m-\mathrm{H}$ pyridine), $-0.68(\mathrm{~s}, 3 \mathrm{H}, \mathrm{Ni}-$ $\left.\mathrm{CH}_{3}\right) ;{ }^{13} \mathrm{C}\left\{{ }^{1} \mathrm{H}\right\}$ NMR $\left(100.5 \mathrm{MHz}, \mathrm{C}_{6} \mathrm{D}_{6}, 25^{\circ} \mathrm{C}\right): \delta=167.9$ $(\mathrm{CH}, \mathrm{C} 7), 163.8\left(\mathrm{C}_{\mathrm{q}}, \mathrm{C} 2\right), 162.5\left(\mathrm{C}_{\mathrm{q}}, \mathrm{d},{ }^{1} J_{\mathrm{C}, \mathrm{F}}=242 \mathrm{~Hz}, \mathrm{C} 17\right.$ and $\mathrm{C} 23$ ), 152.0 ( $\mathrm{CH}$ br., $o$-C pyridine) $149.8\left(\mathrm{C}_{\mathrm{q}}, \mathrm{C} 8\right), 149.5$ $(\mathrm{CH}, \mathrm{C} 4), 141.9(\mathrm{CH}, \mathrm{C} 6), 135.9\left(\mathrm{C}_{\mathrm{q}}, \mathrm{d},{ }^{4} J_{\mathrm{C} . \mathrm{F}}=4 \mathrm{~Hz}, \mathrm{C} 14\right.$ and $\mathrm{C} 20), 135.2\left(\mathrm{C}_{\mathrm{q}}, \mathrm{C} 9\right.$ and $\left.\mathrm{C} 13\right), 132.2\left(\mathrm{CH}, \mathrm{d},{ }^{3} J_{\mathrm{C}, \mathrm{F}}=8 \mathrm{~Hz}\right.$, $\mathrm{C} 15, \mathrm{C} 19, \mathrm{C} 21$, and $\mathrm{C} 25), 130.5(\mathrm{CH}, \mathrm{C} 10$ and $\mathrm{C} 12), 126.5$ $(\mathrm{CH}, \mathrm{C} 11), 120.8\left(\mathrm{C}_{\mathrm{q}}, \mathrm{C} 1\right), 115.6\left(\mathrm{CH}, \mathrm{d},{ }^{2} J_{\mathrm{C}, \mathrm{F}}=21 \mathrm{~Hz}, \mathrm{C} 16\right.$, $\mathrm{C} 18, \mathrm{C} 22$, and $\mathrm{C} 24), 97.5\left(\mathrm{C}_{\mathrm{q}}, \mathrm{C} 5\right), 72.6\left(\mathrm{C}_{\mathrm{q}}, \mathrm{C} 3\right),-7.5\left(\mathrm{CH}_{3}\right.$, $\left.\mathrm{Ni}-\mathrm{CH}_{3}\right) ; m$ - and $p$-C pyridine not detected; anal. calcd. for $\mathrm{C}_{31} \mathrm{H}_{28} \mathrm{~N}_{2} \mathrm{OF}_{2} \mathrm{I}_{2} \mathrm{Ni}\left(789.02 \mathrm{~g} \mathrm{~mol}^{-1}\right)$ : C 47.19, $\mathrm{H}$ 2.81, N 3.55; found: C 47.67, H 3.21, N 3.10.

Crystallographic Data for 8c-pyr·0.5pentane: Crystals suitable for X-ray diffraction analysis were grown from dichloromethane after layering with pentane. $\mathrm{C}_{33.5} \mathrm{H}_{28} \mathrm{~N}_{2} \mathrm{~F}_{2} \mathrm{I}_{2} \mathrm{ONi}, M_{r}=825.09$, triclinic, space group $P-1$, $a=11.8118(18), \quad b=12.6882(19), \quad c=112.7622(19) \AA, \quad \alpha=$ $106.513(3), \beta=110.802(3), \gamma=103.920(3)^{\circ}, V=1584.9(4) \AA^{3}$, $Z=2, \rho_{\text {calcd }}=1.716, \mu=26.0 \mathrm{~cm}^{-1}$, no. of rflns measd $=12338$, no. of unique rflns $=6820$, no. of rflns $I>2 \sigma(I)=4443, R 1$ $[I>2 \sigma(I)]=0.0320, \quad R 1($ all $\quad$ data $)=0.0619, \quad w R_{2}=0.0729$, $2 \theta_{\max }=54.0^{\circ}, T=293(2) \mathrm{K}, \mathrm{GOF}=0.920$. The intensity data were collected on a Bruker AXS CCD diffractometer with a graphite-monochromated $\mathrm{Mo}_{\mathrm{K} \alpha}$ radiation $(0.71070 \AA)$. The structure was solved by direct methods with SHELXS-97 and refined by full matrix least-squares on $F^{2}$ using SHELXL-97. Pentane is disordered and refined over two split positions. Hydrogen atoms were treated in a riding model. CCDC-629990 contains the supplementary crystallographic data for this paper. These data can be obtained free of charge from The Cambridge Crystallographic Data Centre via http://www.ccdc.cam.ac.uk/data/products/csd/ request.cif.

Complex 8e-pyr $\left(\mathbf{R}^{\prime}=\mathbf{M e}\right)$ : Following the general procedure complex 8e-pyr was obtained from [(tmeda) $\left.\mathrm{Ni}\left(\mathrm{CH}_{3}\right)_{2}\right]$ (40.8 mg, $200 \mu \mathrm{mol})$, salicylaldimine 7e $(126 \mathrm{mg}, 200 \mu \mathrm{mol})$ and pyridine ( $240 \mathrm{mg}, 3.04 \mathrm{mmol}$ ) as an orange-red powder; yield: $130.8 \mathrm{mg}(167.4 \mu \mathrm{mol}, 84 \%) .{ }^{1} \mathrm{H}$ NMR $(399.8 \mathrm{MHz}$, $\mathrm{CD}_{2} \mathrm{Cl}_{2}, 25^{\circ} \mathrm{C}$ ): $\delta=8.25$ (m br., $2 \mathrm{H}, o-\mathrm{H}$ pyridine), 7.93 (s, $1 \mathrm{H}, 4-\mathrm{H}), 7.66(\mathrm{vd}, J=8.0 \mathrm{~Hz}, 4 \mathrm{H}, 15-, 19-, 21-$, and 25-H), $7.33\left(\mathrm{~d},{ }^{3} J_{\mathrm{H}, \mathrm{H}}=7.6 \mathrm{~Hz}, 2 \mathrm{H}, 10-\right.$ and $\left.12-\mathrm{H}\right), 7.09(\mathrm{~m}, 2 \mathrm{H}, 7-$ and $11-\mathrm{H}), 7.08(\mathrm{vd}, J=8.0 \mathrm{~Hz}, 4 \mathrm{H}, 16-, 18-, 22-$, and $24-\mathrm{H})$, 7.04 (m br., $1 \mathrm{H}, p-\mathrm{H}$ pyridine), 6.87 (s, 1H, 6-H), $6.30(\mathrm{~m}$ br., $2 \mathrm{H}, m-\mathrm{H}$ pyridine $), 2.05\left(\mathrm{~s}, 6 \mathrm{H}, 17-\right.$ and $\left.23-\mathrm{CH}_{3}\right),-0.54$ (s, 3 H, Ni-CH $\left.\mathrm{CH}_{3}\right) ;{ }^{13} \mathrm{C}\left\{{ }^{1} \mathrm{H}\right\}$ NMR $\left(100.5 \mathrm{MHz}, \mathrm{CD}_{2} \mathrm{Cl}_{2}, 25^{\circ} \mathrm{C}\right)$ : $\delta=167.9(\mathrm{CH}, \mathrm{C} 7), 163.7\left(\mathrm{C}_{\mathrm{q}}, \mathrm{C} 2\right), 152.0(\mathrm{CH}$ br., $o-\mathrm{C}$ pyridine $), 149.9\left(\mathrm{C}_{\mathrm{q}}, \mathrm{C} 8\right), 149.1(\mathrm{CH}, \mathrm{C} 4), 142.0(\mathrm{CH}, \mathrm{C} 6), 137.4$ $\left(\mathrm{C}_{\mathrm{q}}, \mathrm{C} 9\right.$ and $\left.\mathrm{C} 13\right), 136.9\left(\mathrm{C}_{\mathrm{q}}, \mathrm{C} 17\right.$ and $\left.\mathrm{C} 23\right), 136.2\left(\mathrm{C}_{\mathrm{q}}, \mathrm{C} 14\right.$ and $\mathrm{C} 20), 130.6(\mathrm{CH}, \mathrm{C} 15, \mathrm{C} 19, \mathrm{C} 21$, and $\mathrm{C} 25), 130.3(\mathrm{CH}$, $\mathrm{C} 10$ and $\mathrm{C} 12), 129.5(\mathrm{CH}, \mathrm{C} 16, \mathrm{C} 18, \mathrm{C} 22$, and $\mathrm{C} 24), 126.5$ $(\mathrm{CH}, \mathrm{C} 11), 123$ (br., $m$-C pyridine), $121.0\left(\mathrm{C}_{\mathrm{q}}, \mathrm{C} 1\right)$, $97.5\left(\mathrm{C}_{\mathrm{q}}\right.$, C5), $72.3\left(\mathrm{C}_{\mathrm{q}}, \mathrm{C} 3\right), 21.1\left(\mathrm{CH}_{3}, 17-\right.$ and $\left.23-\mathrm{CH}_{3}\right),-7.4\left(\mathrm{CH}_{3}\right.$, $\left.\mathrm{Ni}-\mathrm{CH}_{3}\right)$; $p$-C pyridine not detected; anal. calcd. for $\mathrm{C}_{33} \mathrm{H}_{28} \mathrm{~N}_{2} \mathrm{OI}_{2} \mathrm{Ni}\left(781.09 \mathrm{~g} \mathrm{~mol}^{-1}\right)$ : C 50.74, H 3.61, N 3.59; found: C 51.11, H 3.98, N 3.70.

Complex 8f-pyr $\left(\mathbf{R}^{\prime}=\boldsymbol{t}\right.$-Bu): Following the general procedure compound 8f-pyr was obtained from [(tmeda)Ni$\left.\left(\mathrm{CH}_{3}\right)_{2}\right](40.8 \mathrm{mg}, 200 \mu \mathrm{mol})$, salicylaldimine $\mathbf{7 f}(142.6 \mathrm{mg}$, $200 \mu \mathrm{mol})$ and pyridine $(240 \mathrm{mg}, 3.04 \mathrm{mmol})$ as a red powder; yield: $151.0 \mathrm{mg}(174.6 \mu \mathrm{mol}, 87 \%)$. ${ }^{1} \mathrm{H}$ NMR $\left(399.8 \mathrm{MHz}, \mathrm{C}_{6} \mathrm{D}_{6}, 25^{\circ} \mathrm{C}\right): \delta=8.21$ (m br., $2 \mathrm{H}, o-\mathrm{H}$ pyridine), $7.94(\mathrm{~s}, 1 \mathrm{H}, 4-\mathrm{H}), 7.70$ and $7.39\left(\mathrm{~d}: \mathrm{m}, J_{\mathrm{H}, \mathrm{H}}=8.0 \mathrm{~Hz}\right.$, 4:4 H, 15-, 16-, 18-, 19-, 21-, 22-, 24-, 25, 10- and 12-H), 7.14 $(\mathrm{m}, 1 \mathrm{H}, 11-\mathrm{H}), 7.08(\mathrm{~s}, 1 \mathrm{H}, 7-\mathrm{H}), 6.79(\mathrm{~s}, 1 \mathrm{H}, 6-\mathrm{H}), 6.67(\mathrm{~m}$ br., $1 \mathrm{H}, p$-H pyridine), 6.35 (m br., $2 \mathrm{H}, m$-H pyridine), 1.21 $(\mathrm{s}, 18 \mathrm{H}, 2 \times t-\mathrm{Bu}),-0.53\left(\mathrm{~s}, 3 \mathrm{H}, \mathrm{Ni}-\mathrm{CH}_{3}\right) ;{ }^{13} \mathrm{C}\left\{{ }^{1} \mathrm{H}\right\}$ NMR $\left(100.5 \mathrm{MHz}, \mathrm{C}_{6} \mathrm{D}_{6}, 25^{\circ} \mathrm{C}\right): \delta=167.9(\mathrm{CH}, \mathrm{C} 7), 163.7\left(\mathrm{C}_{\mathrm{q}}\right.$, $\mathrm{C} 2), 151.9(\mathrm{CH}, o-\mathrm{C}$ pyridine $), 150.2\left(\mathrm{C}_{\mathrm{q}}, \mathrm{C} 17\right.$ and $\left.\mathrm{C} 23\right)$, $150.0\left(\mathrm{C}_{\mathrm{q}}, \mathrm{C} 8\right), 149.0(\mathrm{CH}, \mathrm{C} 4), 141.9(\mathrm{CH}, \mathrm{C} 6), 137.5$ and $136.3\left(\mathrm{C}_{\mathrm{q}}\right.$ each, C9, C13, C14 and C20), 135.7 (CH, p-C pyridine), 130.6 and 130.2 ( $\mathrm{CH}$ each, $\mathrm{C} 15, \mathrm{C} 16, \mathrm{C} 18, \mathrm{C} 19, \mathrm{C} 21$, $\mathrm{C} 22, \mathrm{C} 24$ and $\mathrm{C} 25), 126.7(\mathrm{CH}, \mathrm{C} 11), 125.7(\mathrm{CH}, \mathrm{C} 10$ and C12), $122.8(\mathrm{CH}, m-\mathrm{C}$ pyridine $), 121.4\left(\mathrm{C}_{\mathrm{q}}, \mathrm{C} 1\right), 97.6\left(\mathrm{C}_{\mathrm{q}}\right.$, C5), $71.8\left(\mathrm{C}_{\mathrm{q}}, \mathrm{C} 3\right), 34.6\left(\mathrm{C}_{\mathrm{q}}, t-\mathrm{Bu}\right), 31.4\left(\mathrm{CH}_{3}, 2 \times t-\mathrm{Bu}\right),-7.9$ $\left(\mathrm{CH}_{3}, \mathrm{Ni}-\mathrm{Me}\right)$; anal. calcd. for $\mathrm{C}_{39} \mathrm{H}_{40} \mathrm{~N}_{2} \mathrm{OI}_{2} \mathrm{Ni}$ $\left(865.26 \mathrm{~g} \mathrm{~mol}^{-1}\right)$ : C 54.14, H 4.66, N 3.24; found: C 55.00, H 5.21, N: 2.78

Complex 8g-pyr $\left(\mathbf{R}^{\prime}=\mathbf{O M e}\right)$ : Following the general procedure compound 8g-pyr was obtained from [(tmeda)Ni$\left(\mathrm{CH}_{3}\right)_{2}$ ] $(40.8 \mathrm{mg}, 200 \mu \mathrm{mol})$, salicylaldimine $7 \mathbf{g}(132.2 \mathrm{mg}$, $200 \mu \mathrm{mol})$ and pyridine $(240 \mathrm{mg}, 3.04 \mathrm{mmol})$ as an orangered powder; yield: $136 \mathrm{mg}(167.2 \mu \mathrm{mol}, 84 \%)$. ${ }^{1} \mathrm{H}$ NMR (399.8 MHz, $\mathrm{CD}_{2} \mathrm{Cl}_{2} 25^{\circ} \mathrm{C}$ ): $\delta=8.46$ (m br., $2 \mathrm{H}, o-\mathrm{H}$ pyridine), $7.87\left(\mathrm{~d},{ }^{4} J_{\mathrm{H}, \mathrm{H}}=2.0 \mathrm{~Hz}, 1 \mathrm{H}, 4-\mathrm{H}\right), 7.59(\mathrm{vd}, J=8.8 \mathrm{~Hz}$, 4H, 15-, 19-, 21-, and 25-H), 7.49 (s, 1 H, 7-H), 7.32 (m, 3H, $10-12-\mathrm{H}), 7.08$ (vd, $J=8.8 \mathrm{~Hz}, 4 \mathrm{H}, 16-, 18-, 22-$, and $24-\mathrm{H})$, 7.05 (m br., $2 \mathrm{H}, m-\mathrm{H}$ pyridine) $7.02\left(\mathrm{~d},{ }^{4} J_{\mathrm{H}, \mathrm{H}}=2.0 \mathrm{~Hz}, 1 \mathrm{H}\right.$, 6-H), 3.87 (s, $6 \mathrm{H}, 17-$ and $\left.23-\mathrm{OCH}_{3}\right),-1.06$ (s, $\left.3 \mathrm{H}, \mathrm{Ni}-\mathrm{CH}_{3}\right)$; $p$-H pyridine not detected; ${ }^{13} \mathrm{C}\left\{{ }^{1} \mathrm{H}\right\}$ NMR $(100.5 \mathrm{MHz}$, 
$\left.\mathrm{CD}_{2} \mathrm{Cl}_{2}, 25^{\circ} \mathrm{C}\right): \delta=166.7(\mathrm{CH}, \mathrm{C} 7), 162.6\left(\mathrm{C}_{\mathrm{q}}, \mathrm{C} 2\right), 158.5$ $\left(\mathrm{C}_{\mathrm{q}}, \mathrm{C} 17\right.$ and $\left.\mathrm{C} 23\right), 151.2$ ( $\mathrm{CH}$ br., $o-\mathrm{C}$ pyridine $), 148.9\left(\mathrm{C}_{\mathrm{q}}\right.$, C8), $148.1(\mathrm{CH}, \mathrm{C} 4), 141.2(\mathrm{CH}, \mathrm{C6}), 134.9$ and $131.7\left(\mathrm{C}_{\mathrm{q}}\right.$ each, C9, C13, C14 and C20), $131.0(\mathrm{CH}, \mathrm{C} 15, \mathrm{C} 19, \mathrm{C} 21$, and $\mathrm{C} 25), 129.4(\mathrm{CH}, \mathrm{C} 10$ and $\mathrm{C} 12), 125.7(\mathrm{CH}, \mathrm{C} 11), 122.8$ ( $\mathrm{CH}$ br., $m$-C pyridine $), 120.2\left(\mathrm{C}_{\mathrm{q}}, \mathrm{C} 1\right), 113.6(\mathrm{CH}, \mathrm{C} 16$, $\mathrm{C} 18, \mathrm{C} 22$, and $\mathrm{C} 24), 95.9\left(\mathrm{C}_{\mathrm{q}}, \mathrm{C} 5\right), 71.0\left(\mathrm{C}_{\mathrm{q}}, \mathrm{C} 3\right), 54.9\left(\mathrm{CH}_{3}\right.$, 17- and $\left.23-\mathrm{OCH}_{3}\right),-8.7\left(\mathrm{CH}_{3}, \mathrm{Ni}-\mathrm{CH}_{3}\right) ; p-\mathrm{C}$ pyridine not detected; anal. calcd. for $\mathrm{C}_{33} \mathrm{H}_{28} \mathrm{~N}_{2} \mathrm{O}_{3} \mathrm{I}_{2} \mathrm{Ni}\left(813.09 \mathrm{~g} \mathrm{~mol}^{-1}\right)$ : $\mathrm{C}$ 48.75, H 3.47, N 3.45; found: C 48.60, H 3.40, N 3.10.

Complex 8h-pyr $\left(\mathbf{R}^{\prime}=\mathbf{N M e}\right)$ : Following the general procedure complex 8h-pyr was obtained from [(tmeda)Ni$\left.\left(\mathrm{CH}_{3}\right)_{2}\right](40.8 \mathrm{mg}, 200 \mu \mathrm{mol})$, salicylaldimine $7 \mathbf{h}$ (137.5 mg, $200 \mu \mathrm{mol})$ and pyridine $(240 \mathrm{mg}, 3.04 \mathrm{mmol})$ as a deep-red powder; yield: $131.4 \mathrm{mg}$ (131 $\mu \mathrm{mol}, \quad 79 \%) .{ }^{1} \mathrm{H}$ NMR $\left(399.8 \mathrm{MHz}, \mathrm{C}_{6} \mathrm{D}_{6}, 25^{\circ} \mathrm{C}\right.$ ): $\delta=8.39$ (m br., $2 \mathrm{H}, o-\mathrm{H}$ pyridine $), 7.93\left(\mathrm{~d},{ }^{4} J_{\mathrm{H}, \mathrm{H}}=1.8 \mathrm{~Hz}, 1 \mathrm{H}, 4-\mathrm{H}\right), 7.79(\mathrm{vd}, J=8.4 \mathrm{~Hz}$, $4 \mathrm{H}, 15-, 19-, 21-$, and $25-\mathrm{H}), 7.45\left(\mathrm{~d},{ }^{3} \mathrm{~J}_{\mathrm{H}, \mathrm{H}}=7.6 \mathrm{~Hz}, 2 \mathrm{H}, 10-\right.$ and $12-\mathrm{H}), 7.25(\mathrm{~s}, 1 \mathrm{H}, 7-\mathrm{H}), 7.19\left(\mathrm{t},{ }^{3} J_{\mathrm{H}, \mathrm{H}}=7.6 \mathrm{~Hz}, 1 \mathrm{H}, 11-\right.$ $\mathrm{H}), 6.88\left(\mathrm{~d},{ }^{4} J_{\mathrm{H}, \mathrm{H}}=1.8 \mathrm{~Hz}, 1 \mathrm{H}, 6-\mathrm{H}\right), 6.69(\mathrm{vd}, J=8.4 \mathrm{~Hz}$, $4 \mathrm{H}, 16-, 18-, 22-$, and 24-H), 6.65 (m br., $1 \mathrm{H}, p-\mathrm{H}$ pyridine), 6.32 (m br., $2 \mathrm{H}, m-\mathrm{H}$ pyridine), $2.47\left[\mathrm{~s}, 12 \mathrm{H}, 2 \times \mathrm{N}\left(\mathrm{CH}_{3}\right)_{2}\right]$, $-0.42\left(\mathrm{CH}_{3}, \mathrm{Ni}-\mathrm{CH}_{3}\right) ;{ }^{13} \mathrm{C}\left\{{ }^{1} \mathrm{H}\right\}$ NMR $\left(100.5 \mathrm{MHz}, \mathrm{C}_{6} \mathrm{D}_{6}\right.$, $\left.25^{\circ} \mathrm{C}\right): \delta=168.0(\mathrm{CH}, \mathrm{C} 7), 163.6\left(\mathrm{C}_{\mathrm{q}}, \mathrm{C} 2\right), 152.1\left(\mathrm{C}_{\mathrm{q}}\right.$ br., $o-\mathrm{C}$ pyridine $), 149.8\left(\mathrm{C}_{\mathrm{q}}, \mathrm{C} 8, \mathrm{C} 17\right.$, and $\left.\mathrm{C} 23\right), 148.8(\mathrm{CH}, \mathrm{C} 4)$, 142.1 (CH, C6), $136.4\left(\mathrm{C}_{\mathrm{q}}, \mathrm{C} 9\right.$ and $\left.\mathrm{C} 13\right), 135.7$ (CH br., $p-\mathrm{C}$ pyridine), $131.5(\mathrm{CH}, \mathrm{C} 15, \mathrm{C} 19, \mathrm{C} 21$, and $\mathrm{C} 25), 129.6(\mathrm{CH}$, $\mathrm{C} 10$ and $\mathrm{C} 12), 128.4\left(\mathrm{C}_{\mathrm{q}}, \mathrm{C} 14\right.$ and $\left.\mathrm{C} 20\right), 126.5(\mathrm{CH}, \mathrm{C} 11)$, 122.7 (CH br., $m$-C pyridine), $121.5\left(\mathrm{C}_{\mathrm{q}}, \mathrm{C} 1\right), 112.8(\mathrm{CH}$, C16, C18, C22, and C24), $97.4\left(\mathrm{C}_{\mathrm{q}}, \mathrm{C} 5\right), 72.1\left(\mathrm{C}_{\mathrm{q}}, \mathrm{C} 3\right), 40.1$ $\left[\mathrm{CH}_{3}, 2 \times \mathrm{N}\left(\mathrm{CH}_{3}\right)_{2}\right],-7.3\left(\mathrm{CH}_{3}, \mathrm{Ni}-\mathrm{CH}_{3}\right)$; anal. calcd. for $\mathrm{C}_{35} \mathrm{H}_{34} \mathrm{~N}_{4} \mathrm{OI}_{2} \mathrm{Ni}\left(839.17 \mathrm{~g} \mathrm{~mol}^{-1}\right)$ : C $50.09, \mathrm{H}$ 4.08, N 6.68; found: C 50.43, H 54.48, N 6.53 .

\section{General Procedure for the Polymerization of Ethylene in Toluene}

$90 \mathrm{~mL}$ of toluene were cannula-transferred to a $3 \times$ evacuated and argon-filled reactor thermostated to $46^{\circ} \mathrm{C}$. The solvent was saturated $3 \times$ with 5 bar ethylene under stirring (500 rpm) over a total of $15 \mathrm{~min}$. The reactor was vented with a slow ethylene flow (1.1 bar), and $10 \mathrm{~mL}$ of a toluene solution containing the appropriate amount of the respective catalysts 8a-h-pyr were injected by syringe/Teflon cannula. The injection valve was closed, the reactor pressurized with 40 bar ethylene while the temperature rose to $49-50{ }^{\circ} \mathrm{C}$ within $2 \mathrm{~min}$. The temperature of the thermostat was adjusted to $49-50{ }^{\circ} \mathrm{C}$ resulting in a polymerization temperature in the reactor between 49.5 and $51^{\circ} \mathrm{C}$. After stirring at $500 \mathrm{rpm}, 40$ bar ethylene, for the desired reaction time, the reaction was quenched by terminating the ethylene flow, carefully venting the reactor and pouring the reaction mixture into $200 \mathrm{~mL}$ technical grade methanol. The resulting mixtures containing precipitated polyethylenes in case of complexes 8a-d-pyr were stirred for $1 \mathrm{~h}$ at $20^{\circ} \mathrm{C}$, the polymer collected by filtration, washed with $2 \times 50 \mathrm{~mL}$ methanol and $50 \mathrm{~mL}$ of acetone and dried to constant weight under vacuum $\left(50^{\circ} \mathrm{C}, 20\right.$ mbar $)$.

In case of polyethylenes obtained with complexes $\mathbf{8 e - g -}$ pyr work-up was as follows: The homogenous solution was evaporated to dryness under reduced pressure $\left(60-80^{\circ} \mathrm{C}\right.$, $500-20 \mathrm{mbar}$ ). To the resulting highly viscous orange-yellow- ish oil was added methanol $(10 \mathrm{~mL})$, the resulting mixture was vigorously stirred for $30 \mathrm{~min}$ at $55^{\circ} \mathrm{C}$, the mixture cooled to $0^{\circ} \mathrm{C}$, and the methanol phase decanted. Finally, residual solvent was removed at $50^{\circ} \mathrm{C}, 20$ mbar for $2 \mathrm{~d}$. Characterization data and yields are given in Table 1.

\section{Acknowledgements}

A.B. is grateful to the Alexander von Humboldt Foundation for a research fellowship. S. M. is indebted to the Fonds der Chemischen Industrie. We thank Lars Bolk for DSC and GPC analyses.

\section{References}

[1] For reviews, see: a) S. D. Ittel, L. K. Johnson, M. Brookhart, Chem. Rev. 2000, 100, 1169-1203; b) V. C. Gibson, S. K. Spitzmesser, Chem. Rev. 2003, 103, $283-$ 316; c) S. Mecking, Coord. Chem. Rev. 2000, 203, 325351; d) S. Mecking, Angew. Chem. Int. Ed. Engl. 2001, $40534-540$.

[2] L. K. Johnson, M. C. Killian, M. Brookhart, J. Am. Chem. Soc. 1995, 117, 6414-6415.

[3] a) A. M. A. Bennett, (to Dupont), WO Patent Application 98/27124, 1998; b) B. L. Small, M. Brookhart, A. M. A. Bennett, J. Am. Chem. Soc. 1998, 120, 40494050; c) G. J. P. Britovsek, V. C. Gibson, B. S. Kimberley, G. A. Solan, A. J. P. White, D. J. Williams, Chem. Commun. 1998, 849-850.

[4] a) C. Wang, S. Friedrich, T. R. Younkin, R. T. Li, R. H. Grubbs, D. A. Bansleben, M. W. Day, Organometallics 1998, 17, 3149-3151; b) L. K. Johnson, A. M. A. Bennett, S. D. Ittel, L. Wang, A. Parthasarathy, E. Hauptman, R. D. Simpson, J. Feldman, E. B. Coughlin, (to DuPont), WO Patent Application 98/30609, 1998.

[5] F. A. Hicks, M. Brookhart, Organometallics 2001, 20, 3217-3219.

[6] L. Zhang, M. Brookhart, P. S. White, Organometallics 2006, 25, 1868-1874.

[7] Earlier work on olefin polymerization by late transition metal complexes: a) R. Bauer, H. Chung, G. Cannell, W. Keim, H. van Zwet, (to Shell), US Patent Application A 3637636, 1972; b) R. Bauer, H. Chung, K. W. Barnett, P. W. Glockner, W. Keim, (to Shell), US Patent Application A 3686159, 1972; c) W. Keim, F. H. Kowaldt, R. Goddard, C. Krueger, Angew. Chem. Int. Ed. Engl. 1978, 17, 466-467; d) K. A. Ostoja Starzewski, J. Witte, Angew. Chem. Int. Ed. Engl. 1985, 24, 599-601; e) V. M. Möhring, G. Fink, Angew. Chem. Int. Ed. Engl. 1985, 24, 1001-1003; f) U. Klabunde, S. D. Ittel, J. Mol. Cat. 1987, 41, 123-134.

[8] For late transition metal ethylene oligomerization catalysts see: a) ref. ${ }^{[\mathrm{bb}, \mathrm{c}]}$; b) F. Speiser, P. Braunstein, L. Saussine, Acc. Chem. Res. 2005, 38, 784-794; c) J. Pietsch, P. Braunstein, Y. Chauvin, New J. Chem. 1998, 467-472; d) B. L. Small, M. Brookhart, J. Am. Chem. Soc. 1998, 120, 7143-7144; e) C. M. Killian, L. K. Johnson, M. Brookhart, Organometallics 1997, 16, 20052007; f) S. Y. Desjardins, K. J. Cavell, H. Jin, B. W. 
Skelton, A. H. White, J. Organomet. Chem. 1996, 515, 233-243.

[9] D. P. Gates, S. A. Svejda, E. Oñate, C. M. Killian, L. K. Johnson, P. S. White, M. Brookhart, Macromolecules 2000, 33, 2320-2334.

[10] a) M. Schmid, R. Eberhardt, M. Klinga, M. Leskelä, B. Rieger, Organometallics 2001, 20, 2321-2330. For reports of similar diimine complexes based on terphenylamines see: b) L. S. Moody, P. B. Mackenzie, C. M. Killian, G. G. Lavoie, J. A. jr. Ponasik, A. G. M. Barrett, T. W. Smith, J. C. Pearson, (to Eastman Chemical Company), WO Patent Application 00/50470, 2000; c) A. S. Ionkin, W. J. Marshall, J. Organomet. Chem. 2004, 689, 1057-1063.

[11] D. H. Camacho, E. V. Salo, J. W. Ziller, Z. Guan, Angew. Chem. Int. Ed. Engl. 2004, 43, 1821-1825.

[12] For temperature stability of these catalysts (though in propylene polymerization) see: D. H. Camacho, Z. Guan, Macromolecules 2005, 38, 2544-2546.

[13] C. Popeney, Z. Guan, Organometallics 2005, 24, 11451155.
[14] D. A. Tempel, L. K. Johnson, R. Leigh Huff, P. S. White, M. Brookhart, J. Am. Chem. Soc. 2000, 122, $6686-6700$

[15] a) S. Mecking, A. Held, F. M. Bauers, Angew. Chem. Int. Ed. Engl. 2002, 41, 544-561; b) S. Mecking, J. Claverie, in: Late transition metal polymerization catalysis, (Eds.: B. Rieger, L. S. Baugh, S. Kacker, S. Striegler), Wiley-VCH, Weinheim 2003, pp 231-278; c) J. P. Claverie, R. Soula, Prog. Polym. Sci. 2003, 28, 619-662; d) S. Mecking, Coll. Polym. Sci. 2006, 285, 605-619.

[16] M. Zuideveld, P. Wehrmann, C. Röhr, S. Mecking, Angew. Chem. Int. Ed. Engl. 2004, 43, 869-873.

[17] I. Göttker-Schnetmann, P. Wehrmann, C. Röhr, S. Mecking, Organometallics 2007, 26, 2348-2362.

[18] a) T. R. Younkin, E. F. Connor, J. I. Henderson, S. K. Friedrich, R. H. Grubbs, D. A. Bansleben, Science 2000, 287, 460-462; b) A. Bastero, G. Franciò, W. Leitner, S. Mecking, Chem. Eur. J. 2006, 12, 6110-6116.

[19] C. Hansch, A. Leo, R. W. Taft, Chem. Rev. 1991, 91, 165-195.

[20] J. Jenkins, M. Brookhart, J. Am. Chem. Soc. 2004, 126, $5827-5842$. 